\title{
Can Company Disclosures Discipline State-Appointed Managers? Evidence from Greek Privatizations
}

\begin{abstract}
Stavros Gadinis ${ }^{*}$
Conventional economic theory portrays privatization as a transformative event for a company, even when it is partial and the state maintains control. According to this view, private investors have stronger incentives than voters to monitor management performance and constrain side-payments to political allies of the government. But how exactly can private investors discipline managers they cannot fire? Proponents of privatization place their hopes on disclosure obligations under securities laws, triggered by privatized companies' stock exchange listings. They argue that, because company disclosures can reveal side-payments to government allies and cause private investors to abandon the stock, management should avoid political favoritism after a stock exchange listing.

The Article explores whether investors responded to indications of political favoritism as the above theory would predict. Case study
\end{abstract}

* Assistant Professor, University of California, Berkeley Law School (sgadinis@, law.berkeley.edu). I would like to thank Michelle Anderson, Robert Bartlett, Eli Bukspan, Assaf Hamdani, Gerard Hertig, Ehud Kamar, Amir Licht, Katerina Linos, Saira Mohamed, Mariana Pargendler, Mark Ramseyer, Bertrall Ross, Costanza Russo, James Spindler, and Eric Talley, for their extremely helpful comments and suggestions. This Article was presented at the Back to the State? Government Investment in Corporations and Reregulation Conference, Tel Aviv, June 2011. I would also like to thank the CEGLA center at Tel Aviv University School of Law for inviting me to this conference. Dimitris Pantazis provided excellent research assistance. Apart from where specified, all data for the case studies in this Article are provided in the disclosure documents drafted by OTE, PPC and OPAP in the context of their domestic and international offerings, and their annual reports thereafter. These documents are publicly available, apart from memoranda relating to these companies' private placements, which were obtained by the Bloomberg database and are on file with the author. All documents are listed in the Article's Appendix. 
evidence comes from major privatizations in Greece during the last two decades in telecommunications, energy, and gaming. The Article examines the public disclosures of partially privatized companies in two key areas where the risk of political side-deals and corruption remains high: contracts with suppliers and relationships with labor. Greek companies' disclosure documents included clear indications that payouts to suppliers and labor continued to increase during the period of partial privatization. However, these companies'stocks remained attractive to investors.

\section{INTRODUCTION}

Reports about Greece's potential default on its sovereign debt have dominated the international press since late 2009. Faced with a huge deficit - predicted to exceed $150 \%$ of GDP after new bailout loans ${ }^{1}$ - the Greek state is looking for new ways to raise money. Greece's international lenders and its domestic pro-bailout parties agree on little else apart from the need for additional privatizations ${ }^{2}$ : offers of controlling stakes in state-run companies, concessions for natural monopolies, sales of public land for real estate developments, and cooperation between state entities and private investors for new projects. However, many Greek citizens worry that privatization could amount to a fire sale of the national patrimony to foreign investors. These worries put the feasibility of the privatization program into question. ${ }^{3}$

The Greek public's hostile stance towards privatizations is not new. In the early $1990 \mathrm{~s}$, the conservative government had proposed a large privatization program. The socialist opposition decried this privatization effort as Thatcherite ${ }^{4}$ and won the ensuing elections largely on that platform. Only a few years later, the socialists successfully embarked on their own extensive privatization program, which they justified to the public on radically different grounds. They offered assurances that privatization would be partial and the state would maintain control over privatized resources, so as to avoid abuses. ${ }^{5}$

1 See OECD, Economic Surveys - Greece 65 (2011).

2 See Dimitris Kontogiannis, Papandreou Fights to Convince on Austerity, FIN. Times, Sep. 20, 2011 , at 4.

3 See Kerin Hope \& Ralph Atkins, Greek Unions Stage Mass Strike, Fin. Times, Jun. 28, 2011, http://www.ft.com/int $/ \mathrm{cms} / \mathrm{s} / 0 / 5$ edd 7 a $5 \mathrm{c}-\mathrm{a} 16 \mathrm{e}-11 \mathrm{e} 0$-baa800144feabdc0.html\#axzzlj34IIgsC.

4 See George Pagoulatos, The Politics of Privatisation: Redrawing the PublicPrivate Boundary, 28 W. Eur. POL. 358, 363-64 (2005).

5 Id. at 364. 
Nonetheless, the socialists argued, the country needed the new private owners to transform backwards and corrupt state enterprises. ${ }^{6}$

In Greece, as well as around the world, partial privatizations have become one of the most widespread methods of developing national markets. In many countries, citizens had long associated state monopolies with rampant corruption. Concerned citizens were keen to see private owners constrain the partisan practices of politically appointed managers of state-run companies. They placed their hopes in the institutional framework of the market, such as the increased disclosures of securities laws and the vitality and entrepreneurship of private investors. ${ }^{7}$ For this reason, partial privatizations have been portrayed as combining the best of both worlds: the efficiency of private managers with the public-minded objectives of governments.

Economic theory offers a major justification for the superior performance of private owners in comparison to state officials. As argued by Jean-Jacques Laffont and Jean Tirole, voters have few skills and resources to monitor the performance of state-run companies, as compared to private investors. ${ }^{8}$ Moreover, voters may prioritize goals other than managerial efficiency, even if these goals entail losses for the company. Compared to voters' weak monitoring incentives and diverse priorities, private investors have strong motivations to monitor firm management closely, so as to ensure that managers remain focused on profit maximization. For example, market monitoring will press managers to eliminate payouts to political friends of the government that used to burden the company's profits, and instead enter into arm's length transactions. Moreover, market pressures will compel managers to remove excess employees and improve the productivity of those remaining. In short, under market surveillance, the performance of privatized companies should improve.

6 Costas Simitis, the then Greek Prime Minister, stated with regard to sales of minority stakes through the stock exchange: "Privatization is not an end in itself. We do not sell public companies to simply get rid of them. Privatization is a process that helps the market work better, that helps the company to operate more efficiently, that introduces greater competition." He also noted that public companies would undergo "modemization and restructuring" before the sale of a stake to shareholders. See Costas Simitis, Public Statement (June 30, 2000), available at http://archive.enet.gr/2000/06/30/on-line/keimena/economy/fin1. $\mathrm{htm}$ (Greece) (translated from the Greek by the author).

7 Subjecting state-owned enterprises to market discipline was a key motivation for privatization. For a brief history of privatization, see William Megginson, Privatization and Finance, 2010 AnN. Rev. Fin. ECON. 145, 149.

8 See Jean-Jacques Laffont \& Jean Tirole, A Theory of Incentives in Procurement and Regulation 637 (1993). 
Starting from the above theory, a first wave of empirical studies found that partially privatized companies indeed exhibit an improvement in performance after privatization. However, many of these studies suffer from a key limitation: They do not specify causal mechanisms that can explain the improvement in performance. How exactly do private investors succeed in influencing the state-appointed managers whom they cannot fire? After all, private investors in partial privatizations are in the minority. With the state as a controller, a hostile takeover is extremely unlikely. Some scholars have suggested that managers can use their tenure at partially privatized companies as a stepping stone for their transition to a job in the private sector. However, this argument requires an active market for senior corporate officers, which is lacking in many countries that have engaged in partial privatizations.

In the absence of other mechanisms of market monitoring, private investors can rely only on the company disclosures system mandated in securities laws. Typically, partial privatizations occur through sales of shares to a wide set of investors and a stock exchange listing. Thus, partially privatized companies must comply with the initial and ongoing disclosure obligations that apply to publicly traded firms. These disclosure requirements could force partially privatized firms to reveal politically motivated decisions that hurt their profitability, such as payouts to political allies, if these decisions were of some magnitude. Revelations of political favoritism may be problematic for the government on multiple fronts. Because these disclosures would lead to investors' exiting the stock and put in doubt the government's commitment to creating value for shareholders through its privatization program, management may be expected to avoid such payouts. Moreover, allegations of corruption would hurt the government's reelection prospects. Under the threat of such damaging disclosures, state-appointed managers may limit acts of political favoritism that would have eroded firm profitability, leaving a greater share of the profits for private investors.

Ten or more years after the completion of large-scale privatizations initiated in Greece during the late 1990 s and early $2000 \mathrm{~s}$, the time is ripe for an evaluation of these arguments. Given that the partially privatized companies have exhibited an improvement in performance in the period after the initial sale of a minority stake to private investors, and continue to show improvements as the state sells additional blocks of shares in the private market, have partial privatizations been successful in constraining abuses by state-appointed managers, rooting out political favoritism, and limiting payouts to political allies of the government? This Article looks for indications of political favoritism in each company's management choices, as described in their public disclosure documents. A detailed examination of these companies' public disclosures reveals that, in fact, management choices throughout the 
period of partial privatization raise suspicions of political favoritism and continuous payouts to government allies. Despite the presence of minority private investors, state-appointed managers did not change their attitudes towards their governments' political constituencies. This puzzling finding, the Article claims, can help us better understand the mechanisms through which partial privatization shapes company performance, as well as the limitations of public disclosure as a constraint on managers of state-controlled firms. ${ }^{9}$

This Article examines what securities disclosure obligations can constrain managers of partially privatized firms from offering payouts to government allies and can thus account for these firms' improved performance postprivatization. If the stock market's monitoring mechanisms work effectively, the disclosure documents of partially privatized firms should show that payouts to political allies of the government decrease or disappear altogether. On the other hand, if these disclosure documents contain evidence of continuous payouts to government allies, then the threat of market monitoring would have failed to deter political favoritism.

To identify payouts to political allies of the government, the Article focuses on two key areas of firm activity where the risk of mismanagement, waste, and corruption remains high: contracts with suppliers and relationships with labor. Suppliers' contracts typically represent a significant business deal for all parties involved, since partially privatized companies are often among the largest corporations in the country. Because of the sheer size of these deals, politicians may demand - and suppliers may be willing to offer - sidepayments in order to secure the company's business. These side-payments would typically hurt firm profitability, as suppliers would transfer the costs to the company. Similarly, labor relationships might involve political favors from managers to employees who are also voters. With tens of thousands of employees organized in strong labor unions, these companies" workforces may be a significant source of political support for or opposition to the government. As a result, firm employees may achieve from their state-controlled employer compensation and other rewards beyond those typically offered in the private sector.

9 It should be noticed, however, that improvements in performance may result from factors other than lower levels of political favoritism. For example, partially privatized companies may have continued to enjoy regulatory monopolies or other preferential regulatory treatment. Or, a company may have benefitted from improvements in technology or the launch of new products. Finally, improved performance could simply reflect selection effects, since the government may have chosen to privatize only firms that could offer a promising business proposition. 
To explore whether partial privatizations have imposed market discipline on management, the Article presents case study evidence focusing on the three largest privatizations by the Greek state outside the banking sector: those of OTE (Hellenic Telecommunications Organization), OPAP (Greek Football Prognostics Organization), and PPC (Public Power Corporation). The case studies rely mostly on information provided by these companies in their public disclosures, as well as press reports and other contemporary evidence. ${ }^{10} \mathrm{~A}$ first look at typical measures of firm performance, such as net sales, profits, labor productivity and stock price, reveals improvements after partial privatization. In order to understand whether higher quality disclosures have constrained management conduct, the Article turns to these companies? relationships with their suppliers and their employees, the two constituents that have been the traditional recipients of state favoritism. The Article provides evidence that political motivations continued to dictate the terms of these relationships. Suppliers chosen at the time of full state ownership continued their preferential relationships with these companies, often in return for bribes to politicians, as subsequent criminal prosecutions have shown. Labor unions secured annual pay rises that were higher than the national average, extensive pension benefits, and side payments in the form of overtime that have driven costs per employee to new heights. At least in Greece, then, higher-quality disclosures about partially privatized companies' business did not succeed in constraining payouts to political allies.

The evidence provided in this Article also speaks to another long-standing debate in the literature. It helps us better understand why privatization occurs, despite its potential to uproot long-established practices and benefits and thereby invite opposition to any change. In the case of the Greek partial privatizations, two key interest groups - suppliers and labor - did not resist privatization because their privileges were not threatened.

Despite the continued preferential treatment of suppliers and labor, Greek state-run companies show an improvement in various performance measures, at least on the surface. Improved performance may be due to factors other than market monitoring by private investors. For example, the state may have chosen to privatize only those government enterprises that offered viable business prospects, or it may have pushed managers to introduce new products that turned profitable. Since these firms are unique players in the Greek market in terms of their industry and their size, this Article cannot readily rely on alternative firms, wholly owned either by private parties or by the state, which could serve as a baseline for comparisons. Although the Article provides the typical measures of performance mentioned above as

10 For a list of all documents, see the Article's Appendix. 
indications of improvement under partial privatization, it makes no claim of causal connections between this improvement and minority private ownership.

Still, the evidence presented in this Article suggests that the relationship between minority private investors and the state as controller is more complicated than previously thought. More specifically, the Article shows that while the parameters of these companies' relationships with suppliers and labor had been publicly disclosed, investors did not abandon the stock, as conventional privatization theory would predict. Rather, investors continued to flock to these companies' stock, accepting the higher supplier and labor costs it entails. This Article can only hypothesize about the basis for the mutual understanding between investors and government. Perhaps investors were keen to focus on the returns these businesses generated, while the government saw little reason to change practices once it had secured buyers for the stock. However, initial hopes that political favoritism would disappear once private investors enter a company's shareholding proved overly optimistic, as this Article shows.

This Article proceeds as follows. Part I discusses the two main theories developed to predict the impact of privatizations: the political hypothesis, which posits that private owners do not have the political agenda of state appointees, and the managerial hypothesis, which posits that private owners motivated by profit will do a better job of monitoring a company's business. Part II develops the methodology of this Article. First, it applies the two hypotheses in the context of partial privatizations. The political hypothesis predicts that minority private investors will have little impact on management decisions as long as control remains in the hands of the state. In contrast, the managerial hypothesis emphasizes the role of market monitoring mechanisms, like securities disclosures, which might constrain managerial conduct. Part II also describes case selection. Part III presents the case study on telecommunications, Part IV provides evidence on energy, and Part $V$ on gaming. Part VI concludes.

\section{Understanding Partial Privatization: Main Theories}

The archetypal privatization grants to individual investors the power to conduct an activity previously performed by the state. Sometimes states sell assets to private companies or grant exclusive licenses and monopolies. In other cases, states simply sell back to the private sector industries that had previously been nationalized (e.g., mines in the United Kingdom). Often, states reorganize administrative bureaucracies developed to provide certain 
services, such as managing a national resource, into corporations that can be sold directly to private investors.

Privatization often occurs not in a single sale to a new owner, but gradually, in a series of sales over time. In such partial privatizations, governments divest some of their shareholding to private investors, but maintain a controlling stake for a long period of time, often over a decade. Partial privatizations typically take the form of stock offerings followed by a listing on the national stock exchange. They create a diffuse ownership base consisting of retail investors, typically citizens of the company's home state, and institutional investors, domestic as well as foreign. ${ }^{11}$

Economic theorists initially saw complete privatization as a catalyst against the inefficient and corrupt bureaucracies running state enterprises. Several scholars looked to the U.K. privatizations of the 1980 s, understanding them as successful efforts to reduce excess employment. By contrast, many privatizations in Eastern European and other former Soviet-bloc countries in the 1990 s are widely seen as examples of privatizations that failed, penetrated as they were by the corrupt environment of the late Soviet era. ${ }^{12}$ The consensus among privatization scholars of diverse political convictions is that in order to prevent the looting of privatized firms by their new owners, ${ }^{13}$ states must first strengthen the rule of law and establish an institutional framework that constrains self-dealing. ${ }^{14}$ Partial privatization emerged in part as a response

11 Thus, privatizations through local stock exchanges bolster interest in many countries' equity markets and help build a viable financing alternative for private firms from these countries, see William L. Megginson \& Jeffry M. Netter, From State to Market: A Survey of Empirical Studies on Privatization, 39 J. EcoN. LiT. 321, 372-74 (2001); see also Steven L. Jones et al., Share Issue Privatizations as Financial Means to Political and Economic Ends, 53 J. Fin. Econ. 217 (1999) (providing empirical evidence on the various goals governments may pursue through stock exchange-driven privatizations). Moreover, privatized companies that count foreign investors among their shareholders generally experience higher performance improvements, see, e.g., Simeon Djankov, The Determinants of Enterprise Restructuring in Six Newly Independent States, 41 Comp. Econ. Stud. 75, 79 (1999).

12 See Joseph E. Stiglitz, Globalization and Its Discontents 23 (2002).

13 An extensive literature links the decision to privatize with corruption. For an early empirical account, see Daniel Kaufmann \& Paul Siegelbaum, Privatization and Corruption in Transition Economies, 50 J. INT'L AFFAIRS 419 (1997). For a recent theoretic piece, see David Martimort \& Stéphane Straub, Infrastructure Privatization and Changes in Corruption Patterns: The Roots of Public Discontent, 90 J. Dev. Econ. 69 (2009).

14 See Bernard Black, Reinier Kraakman \& Anna Tarassova, Russian Privatization 
to these concerns; with the state still in control of corporate assets, fears of an irreversible selloff were much reduced. Indeed, governments were more likely to choose partial privatizations in cases of natural monopolies or oligopolies, which might otherwise allow new owners to introduce aggressive prices or to engage in looting. ${ }^{15}$

Over the last decade, a series of studies has demonstrated that, in general, privatization improves the performance of formerly state-owned companies. ${ }^{16}$ Partially privatized firms also exhibit an improvement in performance, although less pronounced on average. ${ }^{17}$ To explain this observation, economic theory has advanced two theories: the political hypothesis, and the managerial hypothesis. Both hypotheses start from a common basis: Contrary to private shareholders, voters cannot adequately monitor the performance of stateowned firms because they lack the necessary information, resources, and organization.

\section{A. The Political Hypothesis}

The political hypothesis suggests that in state-owned firms politicians may use firm resources not to maximize corporate profits, but to promote their own agenda. For example, politicians might subsidize the production of cheap goods or services, pamper friendly labor unions, or offer lucrative side deals to their political allies. ${ }^{18}$ At the same time, they might cut back on capital expenditure aimed at modernizing production technology, funding innovative research or improving workforce skills.

Privatization is offered as the solution to this problem. By privatizing a firm, the government undertakes to stop treating it as a mere extension of its civil service. Proponents of privatization expect the new, private owners to sever

and Corporate Governance: What Went Wrong?, 52 STAN. L. REv. 1731, 1735 (2000).

15 See Megginson \& Netter, supra note 11, at 329. Other scholars argue that monopolies offer to politicians a unique tool for extracting bribes, see Kjetil Bjorvatn \& Tina Søreide, Corruption and Privatization, 21 Eur. J. POL. Econ. 903, 905 (2005).

16 See Saul Estrin et al., Effects of Privatization and Ownership in Transition Economies, 47 J. Econ. LIT. 699, 703 (2009); see also Megginson \& Netter, supra note 11 , at 359 .

17 See Nandini Gupta, Partial Privatization and Firm Performance, 60 J. FIN. 987, 990 (2005).

18 See generally Andrei Shleifer \& Robert W. Vishny, Politicians and Firms, 109 Q.J. ECON. 995 (1994) (arguing that transfers from managers to politicians emerge naturally in state-owned enterprises). 
the ties with political friends in favor of business relationships negotiated at arm's length, restructure labor relationships, update the company's production technology and eliminate other inefficiencies in its operation cycle. In order to succeed, privatizations must be part of a wider reform that ensures the transfer of control to private investors. ${ }^{19}$

However, in partial privatizations, political superiors maintain control of the firm over a prolonged period of time - often over a decade. With no change at the helm, corrupt politicians could still obtain benefits from the corporation. Granted, if the privatized firm is listed, its share price offers a monitoring mechanism more readily available to voters. However, voters may have difficulties interpreting a reduction in share price that may be due to factors unrelated to the company's management. Or their attention might be drawn to electoral issues other than state-run companies' performance. As long as politicians are not penalized come election time, they can disregard the interests of investors and continue to use state-controlled firms to further other goals besides profit maximization, such as offering subsidies to consumers or making payouts to their political friends.

To sum up, the political hypothesis predicts little change in company performance after partial privatization, because there is no change in control. As a result, the performance of partially privatized firms should decline or remain unchanged, rather than improve. This conduct should negatively impact the firm's profitability and stock price, causing private investors to flee the firm.

Contrary to these expectations of the political hypothesis, the empirical record shows that partially privatized firms exhibit an improvement in performance. To explain this shift, scholars have pointed out that partially privatized firms are typically listed on stock exchanges, and are thus subject to market monitoring that is nonexistent in wholly state-owned firms. After all, although the management of a partially privatized firm may still be appointed by political superiors, it also comes under the scrutiny of the market apparatus. Yet, while investors can sell their stock on the market and cause the price to drop, they cannot fire managers or take control of the company. Through what mechanism, then, can non-controlling investors affect the way the company is run? How can monitoring by minority shareholders discipline state-appointed managers? This is the question that the managerial hypothesis explores.

19 See generally Andrei Shleifer, State Versus Private Ownership (NBER, Working Paper No. w6665, 1998), available at http://ssm.com/abstract=226357 (arguing that private ownership should be generally preferable to public ownership when the incentives to innovate are strong). 


\section{B. The Managerial Hypothesis}

While the political hypothesis argues that politicians, in the absence of voter monitoring, will actively exercise their control rights over the company to promote their own agenda, the managerial hypothesis claims that, if monitoring the affairs of the company does not appeal to voters, it is unlikely to appeal to politicians either. Politicians' probability of electoral success does not necessarily depend on the growing profitability of state-owned companies. In other words, politicians might not expect significant returns from managing state enterprises efficiently, and will therefore have little motivation to scrutinize their management. ${ }^{20}$ Consequently, the managerial hypothesis views politicians as remote and disengaged supervisors with little interest in the company, who prefer to turn their attention to issues that carry more weight with the electorate.

By contrast, private owners focused on profit maximization will monitor management more effectively. The managerial hypothesis therefore predicts that as private owners enter the company's share capital, they will make new efforts to monitor management, even if the state continues to control the company. Private owners will find a straightforward monitoring mechanism in a stock exchange listing. Stock prices provide investors with guidance as to firm performance. ${ }^{21}$ Moreover, stock prices offer managers a mark for their performance that might be important for their future career prospects in the market for top executives. ${ }^{22}$ Listed companies are generally subject to more robust corporate governance and internal audit standards, such as a minimum number of independent directors, internal ethics books and procedures, and independent audit committees. Moreover, listed companies are subject to more stringent accounting standards ${ }^{23}$ and to audits by outside auditors. Finally, a listing increases the likelihood of a takeover threat, an important tool for disciplining managers, although takeovers are unlikely when the state is the controlling shareholder.

A stock exchange listing is especially transformative for a company that was previously state-owned, rather than privately held. Many privatized corporations started their lives as rigid government bureaucracies, but the

20 See LAFFOnt \& TiROLE, supra note 8, at 637.

21 For support of the efficient market hypothesis, see Eugene F. Fama, Efficient Capital Markets: A Review of Theory and Empirical Work, 25 J. Fin. 383 (1970).

22 See generally Eugene F. Fama, Agency Problems and the Theory of the Firm, 88 J. POL. ECON. 288 (1980) (describing the role of a market for executives as a disciplining mechanism).

23 Such as the International Financial Reporting Standards (IFRS), which are mandatory for publicly traded companies in Europe. 
corporate form provides their managers with direct authority over their employees without the need to follow a stringent set of rules. ${ }^{24}$ Instead of bureaucratic procedures that are usual for administrative agencies controlled by the state, market-monitoring mechanisms introduce a new layer of outside oversight: stock analysts, rating agencies, and the financial press. In response to these monitoring mechanisms, newly privatized firms must adhere to higher governance requirements. The private entity status provides these companies with access to management consultants, auditors, legal advisers, marketing counsels and other professional service providers that are simply not available to government entities. These firms' ability to tap private resources when necessary sets them apart from other state entities.

The managerial hypothesis, then, assumes that the new private owners will closely monitor the company's affairs, identify weaknesses, and use this information to actively change how the company is run. But in partially privatized firms, private minority investors cannot act upon the information they collect through monitoring mechanisms; they do not have control, the state does. So how exactly does publically available information lead to managerial discipline in partially privatized state-controlled firms? Some studies have examined the incentives of chief executive officers (CEOs) to demonstrate their abilities in turning around a partially privatized firm so as to transition into a potentially better-paid job in another, fully private company. ${ }^{25}$ However, many countries with extensive privatization programs do not have an active market for senior corporate officers. For example, very few firms in Greece would look for a chief executive officer, because most private firms have majority shareholders with long-standing control of the firm's management. In the companies described in this Article, most CEOs had limited management experience at the time of their appointment, and did not follow a business career after their tenure. ${ }^{26}$ Moreover, hostile takeovers, one of the most important management disciplining mechanisms

24 See generally Varouj A. Aivazian, Ying Ge \& Jiaping Qiu, Can Corporatization Improve the Performance of State-Owned Enterprises Even Without Privatization?, 11 J. CoRP. Fin. 791 (2005) (arguing that just corporatization, even without privatization, improved the performance of SOEs in China, and showing that improved efficiency was due to reforms in the internal governance structure of the firm).

25 See Gupta, supra note 17.

26 It is true that the management of privatized firms maintains strong political connections, see Narjess Boubakri, Jean-Claude Cosset \& Walid Saffar, Political Connections of Newly Privatized Firms, 14 J. CorP. FIN. 654 (2008) (noting that eighty-seven out of 245 firms in their sample had a politician or ex-politician on their board of directors). 
for U.S. corporations, are extremely rare in Greece. With the state in control, any takeover attempt would require a direct negotiation with management.

In the absence of disciplining mechanisms such as CEO replacements or takeovers, private investors in Greek partially privatized firms can rely only on the impact of public revelations of mismanagement for the company and the government. Public disclosure of political favors through the company's activity may create various difficulties for the government - and governmentappointed managers. First, such revelations can call into question the government's commitment to producing shareholder value, causing investors to flee the stock and the price to drop. ${ }^{27}$ After all, investors would not like to see their money channeled in support of the government's political agenda. Second, if revelations of political favors and corruption catch the attention of the wider public, they might hurt the government's electoral prospects. In this sense, the enhanced regulation and market supervision accompanying the stock exchange listing might operate as a credible commitment device for the government, both towards voters and towards investors. ${ }^{28}$ Government politicians can rely on market monitoring mechanisms to validly signal to voters that, by partially privatizing state-controlled firms, they make a significant step towards eliminating cronyism and corruption. In addition, politicians can commit to investors that they are determined to turn around inefficiently run companies and focus on maximizing profits by inviting them to monitor partially privatized firms closely.

Based on this argument, once private investors enter into a state-run firm's shareholding structure, and once securities laws start requiring the firm to comply with higher standards of ethical and professional conduct, firm management should refrain from overt grants to the government's political allies. After all, "sunlight is the best disinfectant."29 More specifically, if the risk of public disclosure has a disciplining effect on management, then evidence of political favoritism on these companies' public record should be scarce and hard to come by. If, instead, partially privatized firms' securities documents provide evidence of continuous payouts to government allies,

27 For an argument on how public disclosures can constrain bank managers, see generally Robert Bartlett, Making Banks Transparent, 65 VAND. L. Rev. (forthcoming 2012).

28 Cf. Enrico C. Perotti, Credible Privatization, 85 Am. Econ. Rev. 847, 848 (1995) (seeing partial privatization as a mechanism for credible commitment on behalf of the government, but emphasizing the government's intention to avoid imposing heavy regulation on the company after selling it off).

29 This quote is said to have been coined by Justice Louis Brandeis, in a 1913 article in Harper's Weekly about the benefits of transparency. 
then the threat of public disclosure would have failed to constrain political favoritism.

Which of the predictions above find confirmation in the public records of partially privatized Greek firms? This is the question that the empirical part of the Article sets out to explore. The next Part outlines the Article's case study methodology. First, it identifies areas of firm activity where managers are more likely to engage in politically motivated favors to various constituencies, in order to confirm whether these favors continue openly after privatization. Then, it moves on to provide some background on case selection.

\section{Empirical Expectations and Case Selection}

\section{A. Empirical Expectations: Firm Relationships with Suppliers and Labor Post-Privatization}

This Article joins in the inquiry to identify the mechanism through which partially privatized firms improve their performance, by examining whether disclosures mandated by securities laws on privatized firms' activities constrain actions of political favoritism. To identify evidence of political favors in these companies' public records, the Article examines their disclosures throughout the period of partial state ownership. More specifically, it focuses on two areas of corporate activity that have remained unexplored by empirical inquiries, although scholars have long portrayed them as key sources of inefficiency for state-owned companies: contracts with suppliers, and relationships with labor.

Suppliers interested in the sizeable contracts typically associated with large state-controlled firms might offer politicians financial support in return for preferential allocation of business. Suppliers can benefit from a state-run company's expansion when this leads to increased demand for the supplier's products or services. Conversely, privileged suppliers stand to lose if the state-run company faces increased competition, perhaps through the loss of its regulatory monopoly. Overall, the more important the role of suppliers in the company, and the larger the payouts to them, the greater will be their incentives to influence politicians' decisions. A key indication of suppliers' preferential relationship with state-controlled companies would be abovemarket prices for the goods or services provided. However, the most important supply contracts are typically unique in character, and it is therefore hard to pinpoint whether the consideration suppliers receive is above market levels. Thus, the case studies focus on the size of supply contracts, the identity of suppliers, and any evidence of attempted corruption that has surfaced for these suppliers in connection with the state-run company in question as well as other companies. 
Relationships between state-run companies and their employees often present important challenges. The conflict of interest is stark: Politicians must act as bosses, while also asking for the vote of their employees. Early studies of privatization identified excess employment as the emblematic case of abuse of state assets by politicians for electoral gains. Thus, the reduction of redundant personnel and a boost in labor productivity can indicate successful post-privatization management. Conversely, disproportionate increases in labor costs suggest higher payouts to employees.

The relationships of a partially privatized company with its suppliers and employees offer valuable insights into how the business is run before and after partial privatization. Often, a partially privatized firm maintains the same suppliers and employees from the time it was simply an administrative entity or a government department. Changes in the terms of these relationships can mark a shift in decision-making power from politicians to investors. Thus, by focusing on these two groups, the Article examines how the move away from full state ownership affects the same part of the company's business before and after partial privatization. Moreover, the partial privatization setting offers an opportunity to discuss the impact of market-monitoring mechanisms, given that there is no change in control.

While the Article explores whether management continues to favor political allies of the government, it makes no specific predictions about how these findings are going to affect the company's overall profitability. Private minority investors might possibly fail to curb management's political favoritism but manage to increase profits nevertheless, for example by improving a company's sales efforts or product range. They may also, under partial privatization, prefer that the company continue granting favors to the government's political allies, so as to maintain any preferential regulatory treatment that their companies might have enjoyed. Finally, these companies may show improved performance simply due to selection effects, for example because the government chose to privatize only those entities that did provide a solid business proposition in the long run. By limiting its scope to three companies in one country, this Article cannot speak to these questions, but benefits from the ability to examine in greater depth each company's management practices. The Article's case studies provide some information about company performance in order to help illustrate each company's business activities, but make no claim regarding causal connections between improved performance and the entry of private minority investors into each company's shareholding structure. 


\section{B. Case Selection}

Partial privatizations in Greece offer a great opportunity to study the interplay between political objectives and market-driven initiatives. Greece has the institutional backbone of a developed Western democracy, such as a stable parliamentary democracy, an active judicial enforcement system, an important regional stock exchange, and a long-established domestic banking market. Of course, recent press coverage has dwelled on the much-publicized failures of the Greek administrative state, such as its lapses in accurate statistics, its tax collection system that nurtures tax evasion, and its inefficient public sector employees. Still, these major deficiencies are very different from the institutional gaps that characterized countries such as Russia following the collapse of the Soviet Union.

Most Greek privatizations after the mid-1990s were partial, leading to a significant change in ownership - as private investors bought stock — but no change in control, which remained with the Greek state. Partially privatized Greek companies can thus offer a wealth of performance data originating from the same country, limiting concerns about the influence of unobserved variables such as cultural differences or public attitudes. Moreover, most Greek privatizations followed a common format of a listing on the Athens Stock Exchange, a retail public offering in Greece, and a private placement to institutional investors abroad. Thus, concerns about the impact of different privatization methods on the observed outcomes should be limited. Finally, the Greek state's stock offerings at the time were typically oversubscribed, resulting in a mixed shareholder base of retail Greek and foreign institutional investors for all companies.

The companies in this case study constitute the three largest partially privatized companies in Greece outside the banking sector by market capitalization. In many ways, they reflect the archetypal privatized enterprise. Prior to their privatization, all three companies were administrative bureaus of the Greek state under the direct control of government ministers. Thus, they had never operated in a private market environment; they maintained very elementary accounting records; they did not have a board of directors much less independent directors - but operated under the direction of stateappointed civil servants. As a result, all three companies had a lot of ground to cover in order to be transformed into efficiently run private corporations, leaving ample room for managerial innovations. All three companies used to hold - and some still do - regulatory monopoly licenses, at least for part of their activities. OTE and PPC run utilities of strategic importance to Greece, although not OPAP. Overall, the companies included here are three of the most important privatization experiments of the Greek state. 


\section{Telecommunications: The OTE Privatization}

OTE (the initials in Greek for Hellenic Telecommunications Organization) is the largest telecommunication company in Greece. Since its establishment in 1949 , OTE has benefited from a regulatory monopoly that made it the exclusive provider of landline phone services in the country. Under this monopoly, OTE installed and operated the Greek telecommunications networks and offered phone connections to consumers. In the 1990s, European directives required Member States to open up monopoly-controlled infrastructure to other providers. ${ }^{30}$ As a result, OTE continued to maintain and develop the telecommunications network, but had to allow competitors to use it as well. Since January 1, 2001, OTE has been allowing other landline companies to use its network in return for a fee. By late 2005, OTE's market share in landline services had declined to seventy-five percent. ${ }^{31}$

Despite the gradual decline of its core landline business, OTE expanded aggressively in other activities. In 1998 it established a mobile telecommunications subsidiary, Cosmote, that has since become the leading provider in Greece, despite its late entry in a highly competitive market. OTE also expanded heavily in internet and cable TV services, and launched broadband services in the Greek market in 2003. Even more importantly, OTE has pursued an ambitious international acquisition strategy, aiming to become a major player in southeastern Europe. Starting in 1996, it has acquired subsidiaries in Romania, Bulgaria, Albania, Serbia and Montenegro, active in both landline and mobile telecommunications, some of which have become the market leaders in their countries.

The privatization of OTE evolved over a decade, from 1996 to 2008. The Greek state made an unsuccessful effort to privatize OTE during the conservative New Democracy Government of 1990-1993, through the sale of a controlling stake to a strategic investor. The attempt met with fierce resistance not only from the socialist opposition, but also from other ministers within the government. ${ }^{32}$

30 Commission Directive 2008/63/EC of 20 June 2008 on Competition in the Markets for Telecommunications Services 90/388/EEC, 2008 O.J. (L 162); Commission Directive $96 / 19 / \mathrm{EC}$ of 13 March 1996 amending Directive 90/388/EEC with regard to the Implementation of Full Competition in Telecommunications Markets, 1996 O.J. (L 074).

31 See OTE, Form 20-F, at 33 (2005). OTE maintains its leading position to this date, but has not released specific fixed line market share data after 2005.

32 See generally George Pagoulatos, The Enemy Within: Intragovernmental Politics and Organizational Failure in Greek Privatization, 79 PUB. AdmIN. 125 (2001) (describing how the two ministries with powers over privatization, the National 
A few years later, the socialists, now back in power and eager to increase revenues, began a gradual privatization process, emphasizing that the government would not lose control of the company. In 1996 the government sold OTE stock through a public offering in Greece, and listed OTE on the Athens Stock Exchange. In 1997 the government offered a larger stake in the Greek market as well as to international investors through an offering of Global Depositary Shares that were subsequently traded on the New York Stock Exchange as well as in other European exchanges. The socialists continued to sell OTE stock gradually to a wide base of investors. In 2002, the government decreased its shareholding below fifty percent, but maintained control through voting arrangements. After the conservatives came to power in 2004 they continued the gradual sales. By 2008 Deutsche Telekom (DT) had acquired a significant stake in OTE and expressed an interest in taking over management. The government and DT have formed a strategic partnership, whereby each appoint five out of ten members of the board and must comply with super-majority requirements for certain board decisions. Today the state's shareholding in OTE stands at twenty percent. As of April 2011, OTE is the fourth largest company on the Athens Stock Exchange.

Table 1: Decrease of State Participation in OTE Shareholding (Main Steps)

\begin{tabular}{cccccccccc}
\hline 1995 & 1996 & 1997 & 1998 & 1999 & 2002 & 2005 & 2007 & 2008 & 2009 \\
\hline $100 \%$ & $92.4 \%$ & $81.3 \%$ & $56.1 \%$ & $51.1 \%$ & $44.4 \%$ & $38.7 \%$ & $28 \%$ & $25 \%$ & $20 \%$ \\
\hline
\end{tabular}

\section{A. OTE Performance Post-Privatization}

Since the entry of private investors into OTE's shareholder base, its performance has continuously improved, in line with general predictions in the literature about partially privatized companies. As shown in Figure 1 , its net sales continued to increase as the state's shareholding decreased. Its profits took a hit in 2001, when European rules forced OTE to open its network to competing providers of fixed line telephony, but quickly stabilized and continued their upward trend, the only exception occurring in 2005 , when profits plunged because the company launched an expensive early retirement program. The board decided to record most of the impact of this program in the financial statements of a single year, thus eliminating profits for that year. Similarly, OTE's workforce productivity (calculated as profits per employee

Economy Minister and the Industry Minister, often split ways over various privatization proposals, including OTE's). 
work hours) is also improving, as shown in Figure 2. Since 1994, OTE has been gradually reducing its employees, albeit sometimes at a high cost. Finally, OTE's stock price shows improvement from its initial listing and up to 2008 , when the government passed control to private investors, although it underperformed the Athens stock exchange composite index for the same period, as shown in Figure 3.

Figure 1: OTE Profits and Sales in Connection with State Ownership

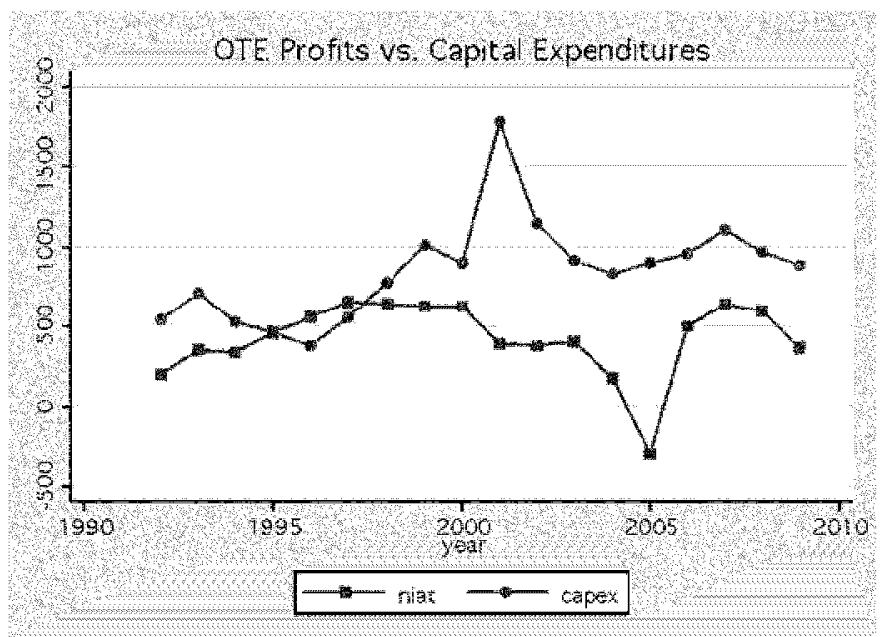

Figure 2: OTE Labor Productivity and Total Number of Employees

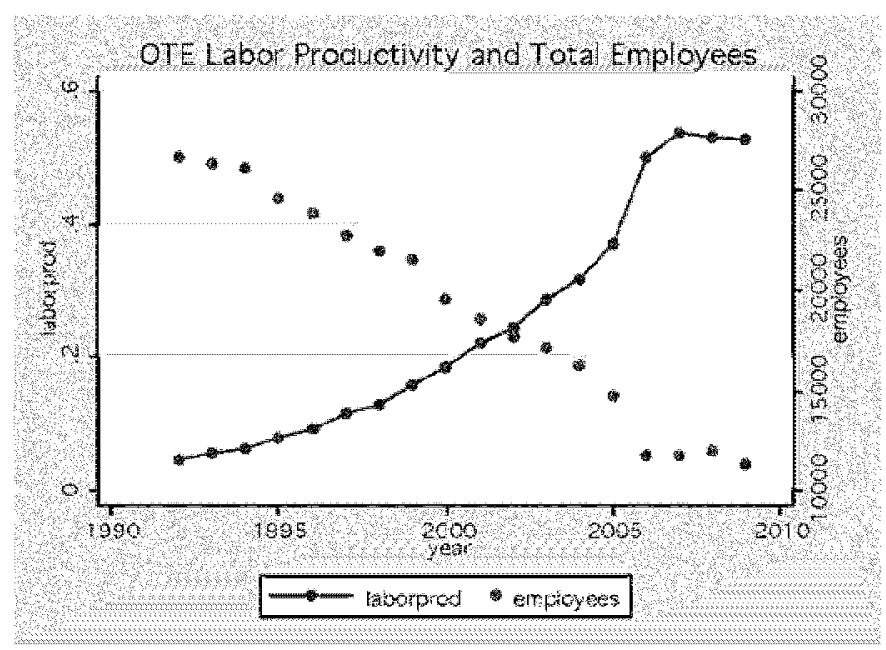




\section{Figure 3: OTE Stock Performance Post-Privatization ${ }^{33}$}

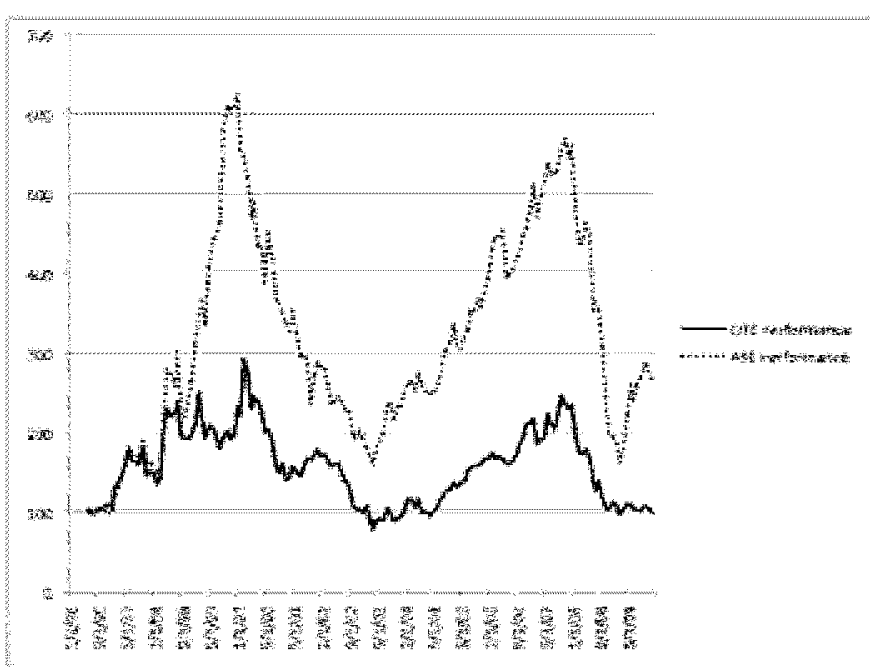

Of course, these aggregate measures on their own cannot confirm that privatization is the single, or even the most important, cause of OTE's improved performance. These trends began when OTE was still a fully stateowned enterprise and may therefore reflect the government's policy rather than the impact of private shareholders. Moreover, Greece at the time was experiencing stellar growth rates, which probably increased demand for OTE's services and fueled improved performance. A more detailed inquiry would take such factors into account. However, having noted that OTE's measures are in line with multiple other studies that have more thoroughly documented the improved performance of partially privatized entities, in the next Sections I will focus on the company's conduct after privatization.

\section{B. Post-Privatization OTE and Major Suppliers}

Particularly intriguing is OTE's decision to pursue an aggressive capital expenditure plan. The company undertook to digitize Greece's telecommunication infrastructure, a long process that continued throughout the period discussed here. The program continued apace even after OTE was forced to allow competitors to use its newly updated network.

Generally, a company's decision to invest in new equipment shows that its management is engaged with the company's long-term prospects and

33 Data for OTE's, PPC's, and OPAP's stock prices and for the Athens Stock Exchange Composite Index are from Datastream. 
preparing the ground for its future movements. For this reason, some studies have used high capital expenditure as an indication of prudent management of the company's activities by its owners. After all, such investments reflect assets owned by the company that will hopefully benefit shareholders in the future. In a company still controlled by the government, increased capital expenditure suggests that profits will remain invested in the company's own activities instead of being siphoned off to the state treasury. Indeed, compared to the prospect of the state looting the company as a controlling shareholder, its decision to increase the company's capital expenditure sounds reassuring.

Yet a closer look at OTE's decisions reveals a more complicated reality. First, the sheer magnitude of OTE's capital expenditure directed towards the purchase of plant or equipment was extraordinary compared to its annual profits. As Figure 4 demonstrates, the company's investments (capex, in millions of Euros) were higher than its net earnings (niat, in millions of Euros) for many years, and showed an upward trend throughout the period. They spiked significantly around 2001, when the network digitization was at full speed, but continued to remain high even after this project was completed. Second, a significant part of these capital expenditures was actually directed to two providers: Intracom, a Greek high-tech firm, and Siemens, the German conglomerate. While OTE's disclosure documents do not provide detailed breakdowns of the sums actually paid to these two firms, they repeatedly emphasize OTE's reliance on these two suppliers in their section on "Risk Factors" year after year.

Figure 4: OTE Net Income After Taxes Compared to Capital Expenditures for Plant and Equipment

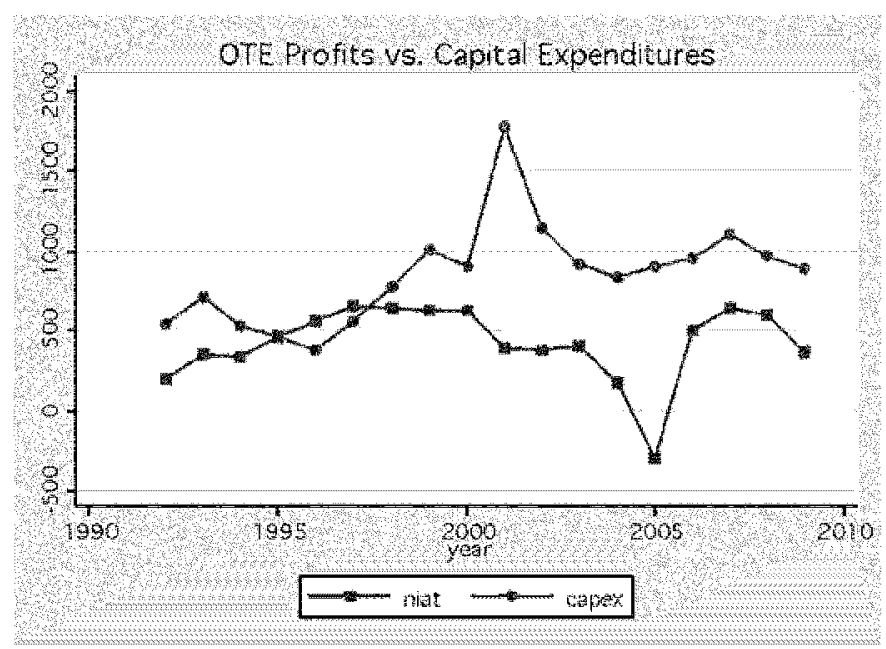


Both firms have a long history of dealings with the Greek state, socialist and conservative governments alike. Intracom is the parent company of Intralot, the company that provides software and betting services to OPAP, the state-owned company that will be discussed in Part V below. Although the Greek press has often alluded to potential connections between Intracom and various politicians, no concrete evidence of misconduct has emerged to date. By contrast, Siemens' efforts to bribe various Greek politicians have recently come to light, as a result of a far-reaching probe undertaken by German authorities since 2005. In particular, Tasos Mandelis, the socialist Telecommunications Minister between 1997 and 2000, confessed in a parliamentary statement that he received significant payments from Siemens, which he claims to have treated as contributions to his political campaign. Mandelis was directly responsible for the regulatory supervision of OTE, and was a member of OTE's board in the 1980s. ${ }^{34}$ Theodoros Tsoukatos, a key member of the socialist Prime Minister's office, also admitted to receiving payments from Siemens. Investigations against other politicians from both parties are ongoing.

Details of specific transactions between OTE and Siemens or Intracom are not available, and it is therefore hard to quantify specific harm to investors as a result of OTE's decision to award them its supply contracts. Let's pause, however, to consider the circumstances surrounding OTE's high capital expenditures. By virtue of its regulatory monopoly, OTE was the sole outlet in Greece for suppliers of digital network equipment. The socialists vehemently opposed OTE's full sale to private investors in the early $1990 \mathrm{~s}$, and undertook a program of extensive modernization of its network in the late $1990 \mathrm{~s}$ and $2000 \mathrm{~s}$. The main suppliers of plant and equipment for that program were two companies, one of which was found to have bribed state officials in Greece between 1997 and 2000. In most years, the cost of this program far exceeded OTE's profits. In other words, a small group of suppliers with strong ties to politicians ensured exclusive access to the largest telecommunications project in Greece at the time, namely the modernization and upkeep of the country's network infrastructure. These same suppliers were present at OTE before its partial privatization, and continued to work with OTE throughout this period. Partial ownership by private investors does not seem to have changed OTE's relationship with its preferred suppliers.

34 However, the government official responsible for voting on behalf of the government in OTE was the Minister of Finance. Both ministers were ex officio members of OTE's Interministerial Privatization Committee. 


\section{Post-Privatization OTE and Labor Relations}

As early as 1997, OTE's offering documents emphasized the company's efforts to reduce its personnel "by means of natural attrition and early retirement schemes. ${ }^{35}$ As shown in Figure 2, the number of OTE's employees steadily declined throughout the period covered in this study. The personnel reduction should count as a success of the partial privatization program. It suggests that the government-appointed managers did not hesitate to shed excess personnel and risk alienating potential voters in deference to private investors' interests.

A closer look at measures of labor productivity indicates that the underlying reality in OTE is more complicated. For a start, total labor costs rose substantially over this period, even as the number of employees was itself declining. Overall, costs per employee have been increasing at a rate of fourteen percent per year. According to the offering documents, the average wage increase per year stands at about four percent. ${ }^{36}$ The remainder is mostly due to rising payments to the employees' retirement benefit plans, and early retirement schemes. These data suggest that during the period of partial privatization OTE employees secured significant gains in their total compensation. In other words, OTE employees benefited from its improved performance, which allowed the company to make these payments. This observation could help explain why the OTE union, which vehemently opposed a full sale of the company to private investors in the early 1990s, posed no resistance to the socialists' gradual sales of OTE stock in the late $1990 \mathrm{~s}$ and early $2000 \mathrm{~s}$.

Figure 5 shows the total increase in employee costs over this period, including an impressive spike in 2005 . This spike was due to a voluntary retirement scheme benefiting 5216 employees (about thirty percent of OTE's workforce), at an estimated cost of $€ 1,100,000,000$ (an additional payment of about $€ 211,000$ per employee). This is a significant amount, especially if one considers that the annual minimum wage in Greece in 2005 stood at $€ 11,000$ and GDP per capita at about $€ 25,000$. At the time, the average annual cost per employee to OTE (including social security and retirement contributions) stood at $€ 77,000$. The voluntary retirement scheme would allow OTE employees to retire immediately with no reduction in their pension benefits, which typically involve an annual payment of over ninety pereent of their last wage before retirement.

35 See Ote, Offering Circular 51 (1997).

36 See, e.g., OTE, Form 20-F, at 104 (2005). 
Figure 5: OTE Total Labor Costs (in Millions of Euros)

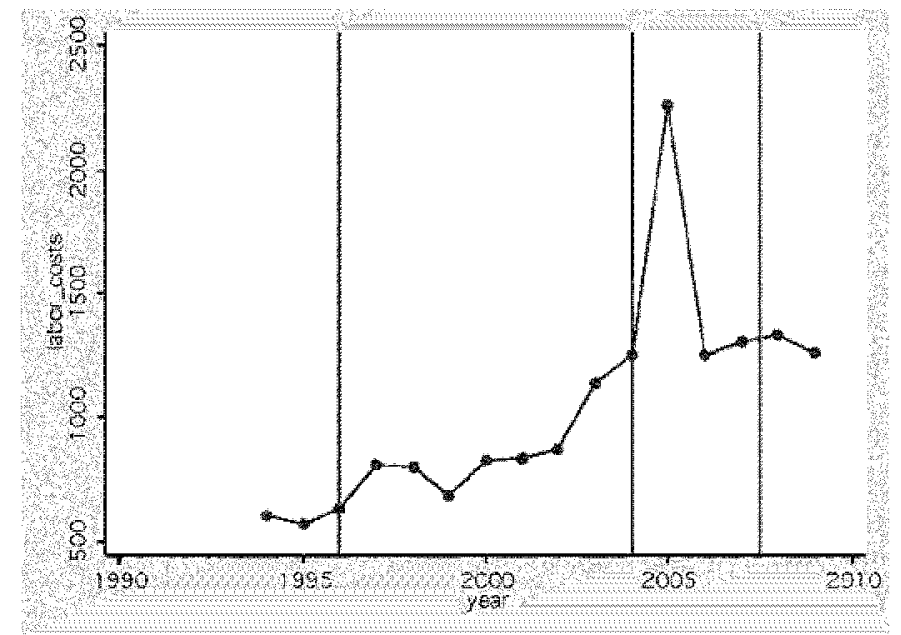

Why would the government provide such generous early retirement terms to OTE employees? The 2005 early retirement scheme was widely seen as the first step in the government's effort to further reduce its shareholding in OTE and cede control to a strategic partner. OTE employees, who had successfully averted the sale of a controlling block by the government in 1993, did not view favorably the latest plan to grant control to private investors. Older employees, trained in earlier times, were especially concerned about the plans of the new private owners. These employees were the primary beneficiaries of the early retirement scheme. In this way, the government paved the way for reducing OTE staff and allowing ample flexibility to private investors to make their own hiring choices. Shortly afterward, in 2006, a Greek private equity fund, MIG, acquired twenty percent of OTE through the stock exchange, thus entering into a takeover battle with the government. The government chose instead a deal with DT, which was completed in late 2007 . Overall, the government used the early retirement scheme as a generous giveaway to labor, in order to secure the success of its privatization plan.

\section{Energy: The Privatization of PPC}

The Public Power Corporation (PPC) is the largest energy company in Greece. It generates energy through various sources and is the sole owner of the power transport and distribution networks in Greece. PPC was first established as a state-owned enterprise in 1950 and was governed by special laws that excluded it from general corporate law. At the time of PPC's establishment, other 
private companies were active in energy generation, but PPC had acquired all of its competitors by the mid-1960s. Since then, PPC had enjoyed an almost complete regulatory monopoly in power generation with very limited exceptions, such as for private enterprises that produced their own power.

As in the case of OTE, European directives in the mid-1990s required the Greek government to dismantle the energy generation and sales' monopoly and open access to the transport and distribution network to other energy providers. ${ }^{37}$ To implement these rules, the government established a new independent regulatory authority for the oversight of the energy market. It also entered into a joint venture with PPC to create a new company to administer the distribution network, still owned by PPC. The new framework became fully operative in 2003, when new providers utilized PPC's distribution network for the first time. PPC maintains its dominant position in the Greek energy market. In 2009, it generated ninety-one percent of the country's energy supply. ${ }^{38}$

To date, the government's stake in PPC remains above fifty-one percent. All sales of stock in PPC occurred during the Socialist Administration. In December 2001, the government conducted a public offering of PPC stocks in Greece and abroad. After this offering, PPC stock was listed on the Athens Stock Exchange and PPC Global Depositary Receipts (GDRs) started trading on the London Stock Exchange. Based on the success of this first offering, the government quickly sold subsequent blocks of PPC stocks to Greek and foreign investors in the next two years. By 2003, the government's stake in PPC was down to $51.5 \%$. Table 2 presents a timeline of the PPC partial privatization.

Table 2: Timeline of Decrease of State Participation in PPC's Shareholding

\begin{tabular}{cccccc}
\hline 2000 & 2001 & 2002 & 2003 & 2004 & 2010 \\
\hline $100 \%$ & $84 \%$ & $71 \%$ & $51.5 \%$ & $51.1 \%$ & $51.1 \%$ \\
\hline
\end{tabular}

37 Directive 96/92/EC of the European Parliament and of the Council of 19 December 1996 Concerning Common Rules for the Internal Market in Electricity, 1996 O.J. (L 27).

38 Pub. Power Corp., Annual Report 2009, at 10 (2010) (Greece), available at http:/www.dei.gr/Documents/DEH\%20Deltio\%202009\%20ENG\%20gray.pdf. 


\section{A. PPC Performance Post-Privatization}

After privatization, PPC has managed to improve its performance on various measures, in accordance with the empirical literature on partially privatized firms and with the performance of OTE and OPAP. Figure 6 presents data on PPC's net sales and revenues against the decreasing state participation. Net sales continued to rise throughout this period, although PPC had to obtain government approval to raise prices. Its profits suffered in 2005, 2006, and 2007 , because of the rising cost of oil and gas supplies that were necessary to generate power. PPC used oil and gas as alternative means of generating power when demand exceeded regular production. Because PPC's regular production network includes many hydroelectric plants that use river water, its costs depend heavily on annual levels of rainfall. The years from 2005 to 2008 were particularly dry years in Greece.

In 2008, a confluence of factors led PPC to register losses for the first time in a decade. First, the national $\mathrm{CO}_{2}$ emission plan, mandated under E.U. laws implementing the Kyoto Protocol, required $\mathrm{PPC}$ to buy $\mathrm{CO}_{2}$ emission rights at a cost of $€ 108,000,000$. A low rainfall season and an eighteen-day employee strike required PPC to rely more on oil- and gas-generated power, at a time of sky-high oil prices. In addition, PPC had to import power from neighboring countries to satisfy demand and avoid blackouts. In 2009 PPC's fortunes improved as rainfall levels were high, bumping PPC's profits higher. Despite these annual fluctuations, PPC's profitability has generally been on the rise since the introduction of private investors into the company's shareholder base.

Figure 6: PPC Salles and Profits in Connection with State Ownership

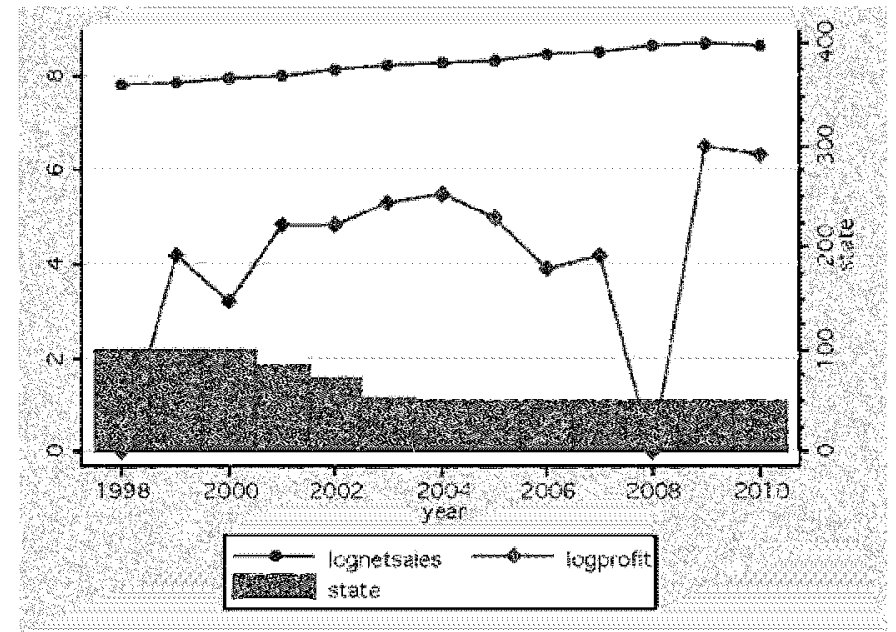


The seasonal trends that affect PPC's profitability also drove lower its labor productivity (calculated as profits per employee hour) between 2005 and 2008, as shown in Figure 7. Yet the company has fulfilled its commitment to reduce its personnel, which has been steadily decreasing since 2000 . The company's stock price has generally outperformed the Athens Stock Exchange composite index since its privatization, as Figure 8 demonstrates.

Figure 7: PPC Labor Productivity and Total Number of Employees

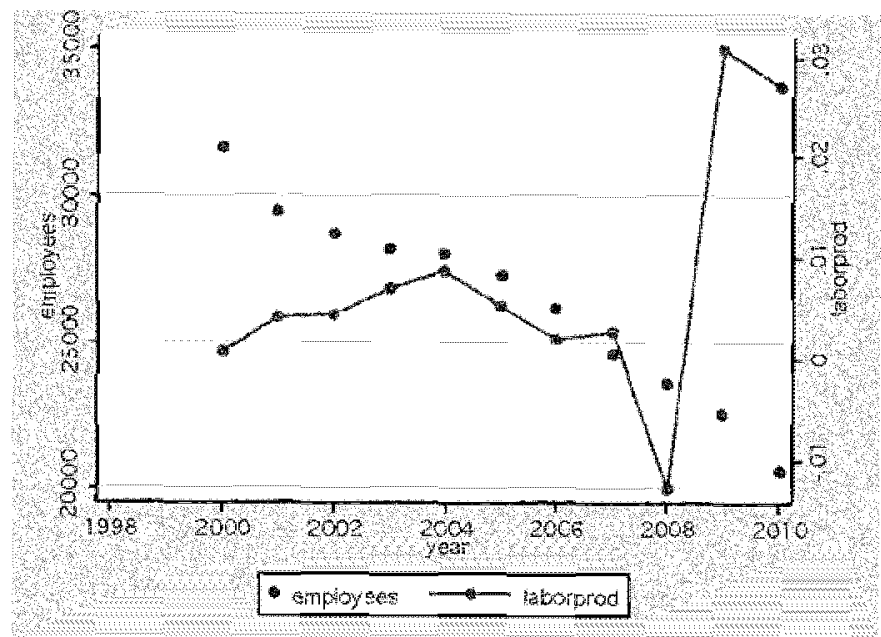

Figure 8: PPC Stock Performance Post-Privatization

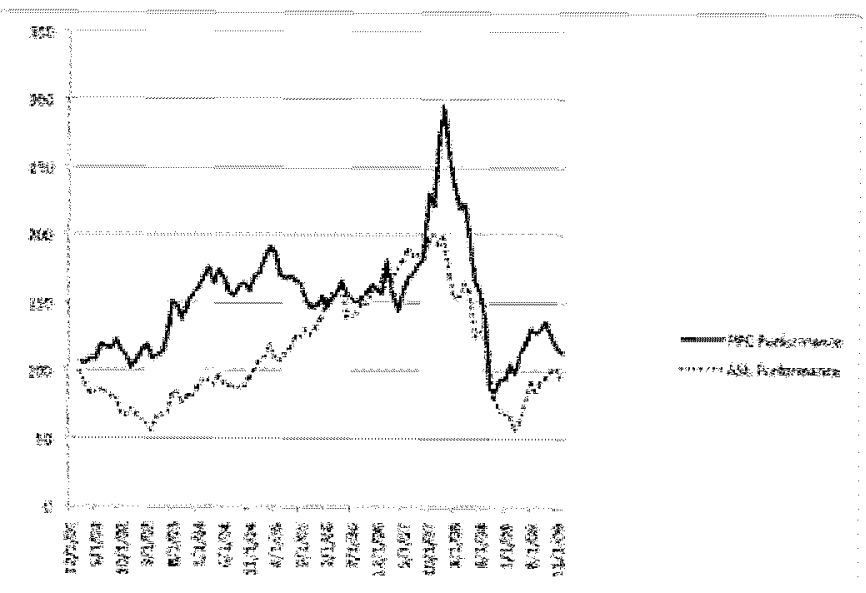




\section{B. Post-Privatization PPC and Major Suppliers}

PPC's major suppliers are providers of raw materials necessary for power generation: oil and natural gas. While PPC owns lignite mines and hydroelectric plants, it relies in part on outside providers of oil and natural gas to satisfy additional demand. Throughout the years studied here, PPC annual reports highlight PPC's dependence on two companies, Hellenic Petroleum and Public Natural Gas Corporation (DEPA, from its acronym in Greek). Both these companies used to be state-controlled entities and are currently undergoing separate privatizations. They both began their relationship with PPC when the state was PPC's sole owner.

PPC's relationship with Hellenic Petroleum is relatively straightforward: PPC acquires oil at prices that reflect international oil indexes. Thus, no state company is allowed to benefit from fluctuation in prices. However, the contours of PPC's relationship with DEPA suggest that PPC's commitment is based on political reasons that may hurt the company's profitability. In 1994, PPC entered into a "take-or-pay" arrangement with DEPA, which requires PPC to pay for a minimum amount of natural gas each year even if it does not use it. This arrangement expires in 2016. At the time, the arrangement was necessary to support the government's decision to import natural gas from Russia. The government awarded DEPA a regulatory monopoly on natural gas, but it also set gas prices. In the mid-2000s, however, European law required the liberalization of the gas market in Greece ${ }^{39}$ Competitors are now offering gas at lower prices than DEPA, but PPC is tied to its DEPA arrangement. Thus, the Greek government's past political moves can limit the flexibility of private investors in pushing for more cost-efficient solutions.

\section{Post-Privatization PPC and Labor Relations}

PPC has long had one of the most powerful labor unions in Greece. Protected by laws that make dismissal all but impossible, and controlling a strategic regulatory monopoly, $\mathrm{PPC}$ employees have enjoyed a very strong bargaining position against successive governments. In cases of extreme conflict with the government in the 1990s, PPC employees did not hesitate to simply switch power off during the night, keeping the whole country in the dark. Moreover,

39 In 2003, the European Union required the liberalization of Member-States" natural gas markets through Directive 2003/55/EC of the European Parliament and of the Council of 26 June 2003 (2003 O.J. L 176/57). This directive was implemented in Greece through Nomos (3428:2005) Apeleftherosi Agoras Fysikou Aeriou [Liberalization of Natural Gas Market], Ephemeris tes Kyverneseos tes Hellenikis Demokratias [E.K.E.D.] 2004, A:313 (Greece). 
for an electoral body as small as that of Greece, 30,000 votes add up to half a percentage point $(0.5 \%)$ in national elections. PPC employees happily turned their strong negotiating position to their advantage: Throughout this period, costs per employee increased at a whopping $9.5 \%$ per year, compared to a $3.1 \%$ average for other public sector employees. ${ }^{40}$ As a result, total labor costs skyrocketed, despite the parallel reduction in employee numbers. Figure 9 shows the rise in labor costs, which increased consistently after partial privatization up to 2010 . The drop in 2010 was not due to a PPC management decision, but the result of a general wage cut in the context of the government's loan agreement with E.U. Member States and the International Monetary Fund (IMF).

\section{Figure 9: PPC Total Labor Costs (in Millions of Euros)}

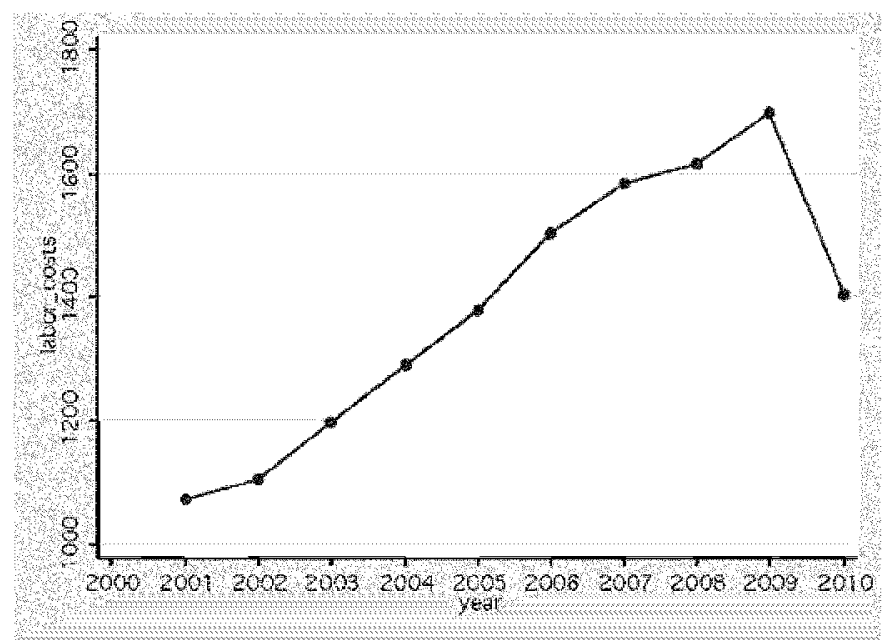

Apart from general increases in wages, PPC's labor union leaders have secured a series of additional perks over the years, as well as additional payments for themselves. PPC employees have access to significantly discounted prices for their power consumption. In April 2011, the General Inspector of Public Administration conducted an official inquiry into the compensation of labor union leadership and payments from PPC to its labor union more generally. According to the General Inspector's report, PPC paid to its labor union an additional $€ 3,000,000$ on average per year, partly to support employee training but partly to organize vacations and trips. ${ }^{41}$ The labor

40 OECD, supra note 1 , at 66.

41 See Gen. Inspector of Pub. Admin., Report on PPC Inspection Regarding the Legality of PPC FinanCial Support/Subsidies Towards the PPC Labor Union 
union leadership spent about $€ 100,000$ per year for trips and other expenses. Payments continued during both Socialist and Conservative Administrations. The report was the basis for a criminal investigation into these expenses that is still ongoing.

Despite this setback to its public image, PPC's labor union leadership has been extremely vocal in its opposition to any further reduction of the state's participation in the company. The labor union consented to PPC's initial privatization only after the state agreed to undertake additional payments to PPC employees' pension funds directly from the state budget and not from the company. ${ }^{42}$ The labor union leaders are threatening to simply switch off power if the state decides to sell any further shareholding that results in a loss of control, or to sell individual PPC plants or other assets.

Overall, the entry of private investors into PPC's shareholding structure did little to push the relationship between the firm and its labor union towards more cost-effective management. Instead, the assertiveness of PPC union leaders and the profligate compensation of PPC employees have become emblematic of union overreach and wasteful public sector spending, widely blamed for Greece's debt problems. Neither private investors' minority rights nor mandatory disclosure requirements have stood in the way of favorable payouts from politicians to PPC labor.

\section{Gaming: The Privatization of OPAP}

OPAP (Greek initials for Greek Football Prognostics Organization) is the largest gaming company in Greece. It enjoys a regulatory monopoly on all sports betting in Greece, as well as an exclusive license to operate a number of existing games and a right of first refusal on future games to be introduced by the state. OPAP's main competition within Greece comes mainly from state lotteries and casinos, as well as illegal betting. While OPAP's monopoly has been challenged in the courts, it has so far been upheld for reasons of public policy. Over the years, OPAP has portrayed itself as a company interested in financially supporting Greek sports events and groups, as well as cultural activities, through an extensive policy of direct grants.

OPAP was founded in 1958 to operate a football prognostics game and later expanded also into lottery-type games, capturing between twenty-five to thirty-

$53(2011)$.

42 According to press reports, the cost of these payments exceeded $€ 5,000,000,000$ in aggregate in the last decade, see, e.g., Constantine N. Stabolis, The Hurdles in Energy Privatizations, IMERISIA, May 5, 2011, http://www.imerisia.gr/article. asp?catid $=12338 \&$ subid $=2 \&$ pubid $=111073182$. 
five percent of the Greek market in games of chance by the $1990 \mathrm{~s} .{ }^{43}$ OPAP became a major player in the Greek gaming market when it first introduced its sports betting game "Stihima" in 2000 , which was extremely popular and immediately led to a fourfold increase in revenues. Soon afterwards, in 2003, OPAP launched a numerical betting game, "Kino," which introduced betting competitions on a continuous basis throughout the day. Kino's success matched that of Stihima and consolidated OPAP's leading position. By 2005 , OPAP had expanded the legal betting market and captured a market share of over fifty percent. ${ }^{44}$

OPAP's privatization occurred through sales to retail investors in Greece and to institutional investors abroad. Before its privatization, OPAP operated under a special regulatory framework as a private nonprofit organization under the direct supervision of the Ministry of Culture and Athletics. To prepare the business for privatization, the government reorganized OPAP into a corporation in 1999 and granted it exclusive regulatory licenses shortly afterwards. OPAP's successful launch of Stihima demonstrated the company's business potential and likely appeal to investors. To take advantage of this success, the government begun a gradual privatization process by first selling a six percent stake in OPAP in 2001 through a public offering and subsequent listing on the Athens Stock Exchange, OPAP's only listing to date. In three further offerings in 2002, 2003, and 2005, the state sold additional shareholding to retail investors in Greece through public offerings and to institutional investors abroad through private placements. Today the state's direct holding stands at thirty-four percent of the company's share capital. However, the laws governing the operation of the company and its exclusive regulatory licenses allow the government to appoint the majority of the members of the board.

Table 3: Decrease of State Participation in OPAP

\begin{tabular}{ccccc}
\hline 1999 & 2001 & 2002 & 2003 & 2005 \\
\hline $100 \%$ & $94.6 \%$ & $75.7 \%$ & $51.3 \%$ & $34 \%$ \\
\hline
\end{tabular}

43 See OPAP, Prospectus 192 (2001).

44 See OPAP, Prospectus 183-84 (2005). 


\section{A. OPAP Performance Post-Privatization}

In accordance with general expectations regarding the performance of partially privatized companies, OPAP's performance improved after the entry of private investors. As shown in Figure 10, sales and profits increased after the introduction of Kino in 2003 and continued to rise through 2008 , when Greece's economic troubles triggered a recession that hit business turnover generally. The same improvement in performance was evident with respect to labor productivity, which increased throughout this period, as shown in Figure 11. The number of OPAP's employees has also decreased compared to pre-privatization levels, although most of the decrease took place in the first few years after 2000 , before the entry of private investors into the company's shareholding structure. Finally, OPAP's stock price has outperformed the Athens Stock Exchange composite index by a significant margin since its initial listing, as shown in Figure 12.

Figure 10: OPAP Sales and Profits in Connection with State Participation

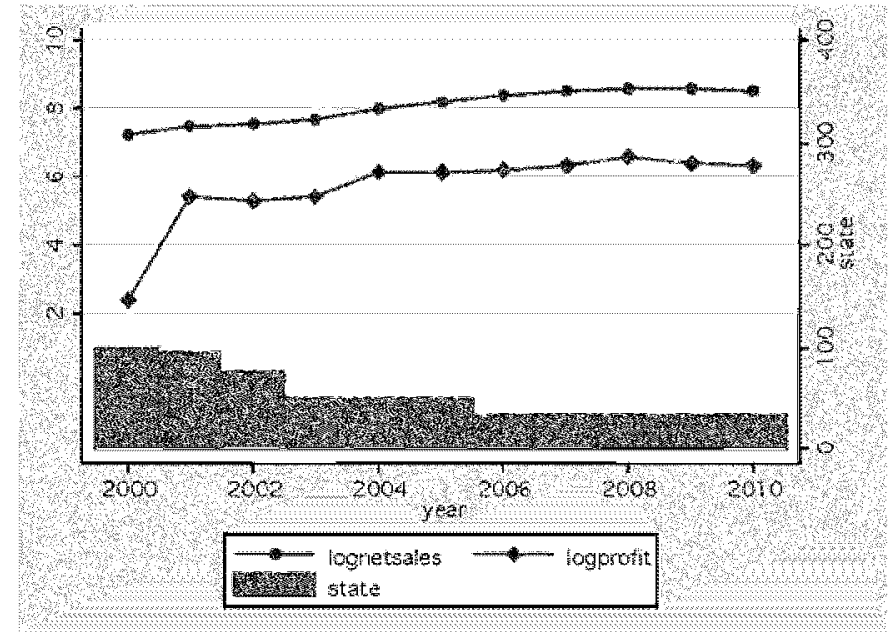


Figure 11: OPAP Labor Productivity and Total Number of Employees

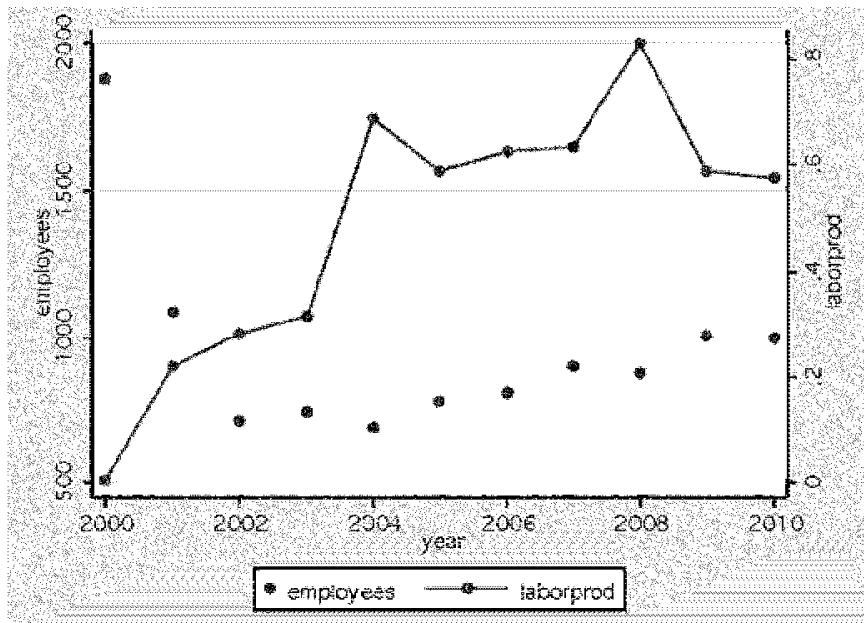

Figure 12: OPAP Stock Price Performance PostPrivatization

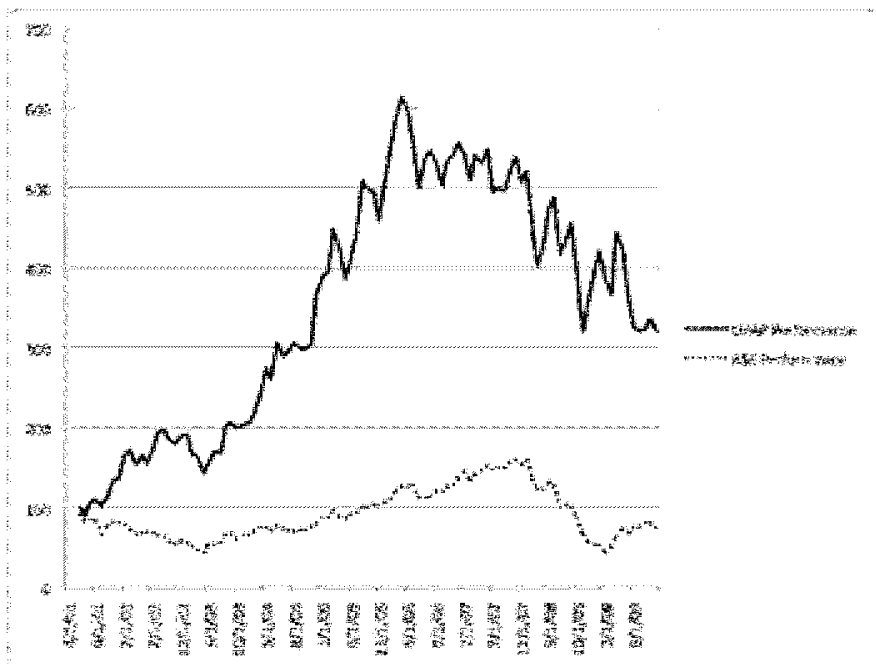




\section{B. Post-Privatization OPAP and Major Suppliers}

Throughout the period studied here, OPAP had a multifaceted relationship with one major external supplier, the Intracom group. Even before OPAP's corporate reorganization in 1999, Intracom provided OPAP with the technology that links its retail outlets to its main gaming platform, the software for its games, and routine technical support and maintenance. At that time, the Intracom group was also a major supplier to OTE, the state-controlled telecommunications company discussed above. ${ }^{45}$

The relationship between OPAP and Intracom expanded significantly when OPAP introduced sports betting through Stihima. Under a sevenyear agreement concluded immediately before OPAP's privatization, OPAP assigned substantial parts of the operation of Stihima to Intralot, an Intracom affiliate: Intralot chose the types of sports and the specific sporting events for the game, set the odds, printed the betting slips, conducted all marketing and promotion, and generally monitored the game. Essentially, Intralot became OPAP's subcontractor. Intralot's compensation was to be calculated on the basis of the game's revenues, starting from eleven percent for the first $€ 58,600,000$ and sliding down to $8.5 \%{ }^{46}$ Intralot also undertook to remunerate OPAP if profits to winners exceeded a certain percentage of revenues, effectively assuming the risk for miscalculations of the odds. Because OPAP was still fully state-owned at the time of the agreement, the assignment of the contract to Intralot was concluded after an international public procurement contest in accordance with E.U. rules. So far, no investigation as to the circumstances surrounding that contest has met with any success.

After the conservatives returned to power in 2004 , they appointed a new CEO and new directors at OPAP. There was a partial renegotiation of the Intralot agreement up to its original expiry date in mid-2007. Afterwards, OPAP and Intralot entered into a new agreement for the gradual transfer of hardware, software and know-how from Intralot to OPAP. During this time, OPAP built its own sports betting team so as to operate the game independently of Intralot.

Figure 13 shows the aggregate payments to Intralot (bottom line) relating to the operation of Stihima throughout this period, in comparison to OPAP's gross profits from Stihima (top line). Thus, it compares the two modes of operation of the game. In the first mode during the years 2000-2006, when Intralot was the main operator, OPAP's profits trailed the payments to Intralot quite closely. This suggests that Intralot recouped a significant percentage of

45 See supra Section III.B.

46 See OPAP, Prospectus 84 (2001). 


\section{Figure 13: OPAP's Gross Profits from Stihima and Payments to Intralot (in Millions of Euros)}

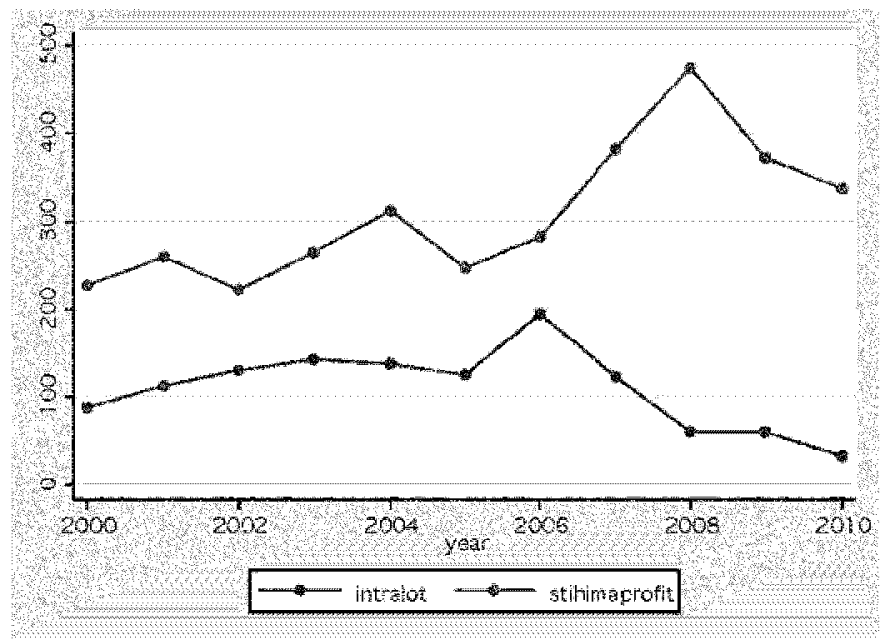

Stihima-generated profits. After 2006, the gap widened as OPAP purchased Intralot's equipment and know-how and built its own capacity. This suggests that this second mode was more profitable to OPAP than the first.

Overall, OPAP's relationship with Intralot continued to be strong as private investors entered the firm's share capital. The contours of that relationship were set by contractual arrangements concluded before OPAP's privatization, which constrained subsequent efforts to renegotiate. Renegotiation was successful only later, when the initial agreement with Intralot drew near its expiry date and it became clear that OPAP would not renew it. Thus, private investors in OPAP did not have the flexibility to revisit the firm's relationship with its suppliers, despite its importance to OPAP's profits.

\section{Post-Privatization OPAP and Labor Relations}

Compared to the massive workforces of OTE and PPC, OPAP's total number of employees is miniscule, having remained at approximately a thousand individuals or less for most of the period discussed here. OPAP sales rely heavily on retail outlets that the company does not own, but operates through independent agents. These agents run their own businesses, which are typically family-run enterprises. As a result, OPAP's labor unions are not as powerful as OTE's or PPC's, and developments in OPAP did not resonate with national labor-capital relations in the same way as in the cases of OTE and PPC. 
Nonetheless, the increase in compensation for OPAP employees is impressive: It rose by an average of seventeen percent between 2002 and $2007 .^{47}$ According to the company's reports, the drop in employee compensation in 2009 and 2010 is partly due to the transfer of highly paid executives from the parent company to one of its subsidiaries. This rate of increase is the highest among the companies included in this Article. Figure 14 shows the increase in total labor costs for the company.

\section{Figure 14: OPAP Total Labor Costs (in Millions of Euros)}

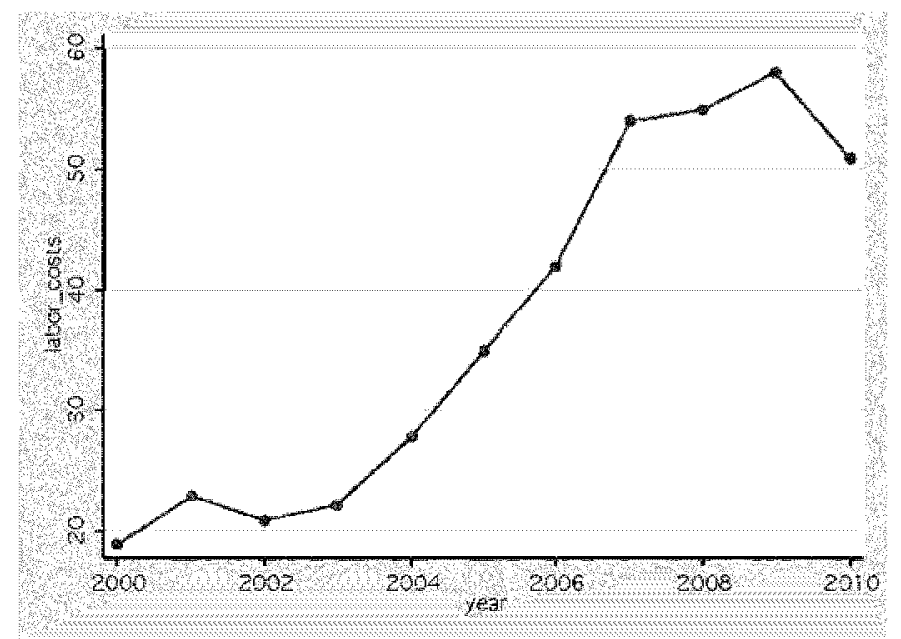

\section{Discussion and Conclusion}

This Article has examined whether disclosure regulation mandated by securities laws constrains managers in partially privatized companies from granting payouts and other favors to political allies of the government. According to the managerial hypothesis, once a formerly state-owned company has obtained a stock exchange listing and expanded its shareholder base to include a new set of private investors, these investors have an incentive to monitor management and increase shareholder value, relying on public disclosures as a key monitoring mechanism. In contrast, the competing political hypothesis argues that managers in partially privatized firms will align with the interests of the government, which remains the controlling shareholder. According to

47 This calculation excludes 2001, when the company's new technology allowed it to downsize significantly by ending its reliance on temporary workers. 
the political hypothesis, payouts to political allies and other political favors will continue as long as privatization remains partial, typically leading to underperforming companies.

This Article has explored the above hypotheses in the context of the three most important Greek privatizations of the last two decades. It finds that despite the increased disclosure obligations of these companies, both in Greece and abroad, they continued to experience high levels of payouts towards two groups that have traditionally enjoyed close ties with the political elite: suppliers and labor unions. These payouts are confirmed through publicly available data released by the companies themselves, and were therefore known to investors at the time. These companies also demonstrate a prima facie improvement in average levels of performance over time, in accordance with general expectations of the literature on partial privatizations.

By identifying the benefits and limitations of securities law disclosures in the context of partial privatization, this Article makes two key contributions to the literature. First, it explores what disclosures mandated by securities laws could reveal about the ability of private investors to monitor management in partially privatized companies. It develops this mechanism theoretically, and examines its strengths and weaknesses empirically. Second, the Article suggests that, although in theory the interests of governing politicians as controlling shareholders and minority investors are antithetical, in practice they may fall in line with one another. This observation is critical because it raises doubts about one key justification that proponents of partial privatization offered: the potential of market monitoring mechanisms to combat political favoritism.

Company disclosures could provide a wealth of information about the relationship between minority investors and state-appointed managers. In most partial privatizations, these disclosures are the only monitoring tool available to minority investors; other commonly suggested channels of influence, such as active markets for corporate control through takeovers or for successful CEOs, are simply non-existent in many countries. In these cases, minority investors' sole means of pressure towards the state is exiting the stock, and investor decisions depend significantly on the company disclosures mandated by securities laws. While securities disclosures are perhaps the most widely available source of information for minority investors, their reactions to these disclosures have not been extensively studied in the literature on partial privatizations. This Article fills the gap, developing theoretically mechanisms through which securities disclosure could affect management choices, and examining whether these theoretical predictions find confirmation in practice.

The Article suggests that, instead of relying on aggregate measures of firm performance, such as measures of profitability or productivity, we 
need to delve deeper and examine what aspects of management conduct investors are likely to monitor. It proposes focusing on privatized companies' relationships with suppliers and labor, since these are areas of well-known potential inefficiencies for state-run companies and they are likely to be at the microscope of private investors. Moreover, the focus on these two areas helps trace indications of related problems in the companies' extensive disclosure documents over multiple years. The Article shows that, based on these disclosures, investors would probably have been able to conclude that state appointed managers continued, and in some cases reinforced, the privileged relationship between the company, on the one hand, and its suppliers and labor, on the other hand. From a substantive standpoint, this finding suggests that public disclosure alone cannot fully deter politically motivated decisions in state-run companies. Despite potential suspicions of favoritism, these companies were very successful in attracting investors and, in some cases, outperforming the Athens Stock Exchange General Index.

This Article can only hypothesize about investors' underlying motivations. Assuming that investors recognize the potential for political favoritism, they also seem to accept that, even if management makes some inefficient choices, the business case for these companies remains strong. Or, investors may conclude that the political privileges these companies were enjoying - in the form of regulatory monopolies or preferential treatment - outweighed, from a business perspective, the inefficiencies introduced by payouts to government allies. In any case, a more nuanced theoretical account of the effects of partial privatization is necessary, before we can safely assess its benefits and costs.

Whatever investors' motivations are, their continued interest in these companies' stocks puts into question one of the key arguments used to justify partial privatizations toward undecided voters: that market monitoring would constrain political favoritism within state-run companies. While higher-quality disclosures may confer other benefits to state-run companies, they do not seem to discourage their managers from pursuing politically motivated objectives. As many policymakers think of partial privatizations as a tool for reforming the structure of a nation's economy and government, in Greece and elsewhere, this conclusion should be questioned. 


\section{Appendix}

\begin{tabular}{|c|c|c|}
\hline Document & Document (in Greek) & Availability \\
\hline \multicolumn{3}{|c|}{ Hellenic Telecommunications Organization (OTE) } \\
\hline $\begin{array}{l}\text { Offering Circular } \\
1997\end{array}$ & & Bloomberg (on file with author) \\
\hline $\begin{array}{l}\text { Annual Report } \\
1997\end{array}$ & & Bloomberg (on file with author) \\
\hline $\begin{array}{l}\text { Annual Report } \\
1998\end{array}$ & & Bloomberg (on file with author) \\
\hline $\begin{array}{l}\text { Annual Report } \\
2000\end{array}$ & 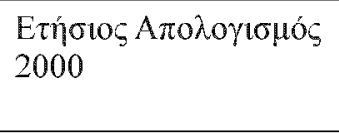 & $\begin{array}{l}\text { http://www.ote.gr/investor/greek/pdfs/ } \\
\text { Annual_Reports/ANNREPGR_2000. } \\
\text { PDF }\end{array}$ \\
\hline $\begin{array}{l}\text { Annual Report } \\
2001\end{array}$ & 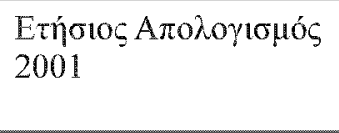 & $\begin{array}{l}\text { http://www.ote.gr/investor/greek/pdfs/ } \\
\text { Annual_Reports/ANNREPGR_2001. } \\
\text { PDF }\end{array}$ \\
\hline $\begin{array}{l}\text { Annual Report } \\
2002\end{array}$ & 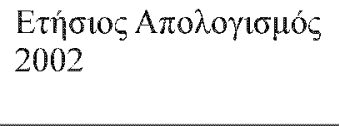 & $\begin{array}{l}\text { http://www.ote.gr/investor/greek/pdfs/ } \\
\text { Annual_Reports/ANNREPGR_2002. } \\
\text { pdf }\end{array}$ \\
\hline $\begin{array}{l}\text { Annual Report } \\
2003\end{array}$ & 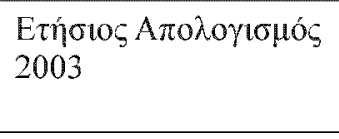 & $\begin{array}{l}\text { http://www.ote.gr/investor/greek/pdfs/ } \\
\text { Annual_Reports/ANNREPGR_2003. } \\
\text { PDF }\end{array}$ \\
\hline $\begin{array}{l}\text { Annual Report } \\
2004\end{array}$ & 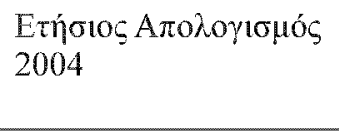 & $\begin{array}{l}\text { http://www.ote.gr/investor/greek/pdfs/ } \\
\text { Annual_Reports/ANNREPGR_2004. } \\
\text { pdf }\end{array}$ \\
\hline $\begin{array}{l}\text { Annual Report } \\
2005\end{array}$ & 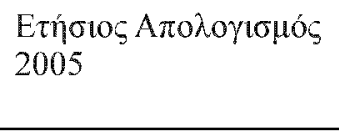 & $\begin{array}{l}\text { http://www.ote.gr/investor/greek/pdfs/ } \\
\text { Annual_Reports/ANNREPGR_2005. } \\
\text { pdf }\end{array}$ \\
\hline $\begin{array}{l}\text { Annual Report } \\
2006\end{array}$ & 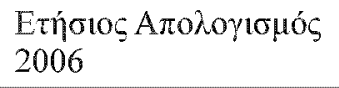 & $\begin{array}{l}\text { http://www.ote.gr/investor/greek/pdfs/ } \\
\text { Annual_Reports/annual06gr.pdf }\end{array}$ \\
\hline $\begin{array}{l}\text { Annual Report } \\
2007\end{array}$ & 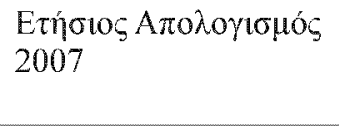 & $\begin{array}{l}\text { http://www.ote.gr/investor/greek/pdfs/ } \\
\text { Annual_Reports/ANNREPGR_2007. } \\
\text { pdf }\end{array}$ \\
\hline $\begin{array}{l}\text { Annual Report } \\
2008\end{array}$ & 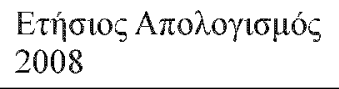 & $\begin{array}{l}\text { http://www.ote.gr/investor/Uploads/ } \\
\text { ann2008gre.pdf }\end{array}$ \\
\hline $\begin{array}{l}\text { Annual Report } \\
2009\end{array}$ & 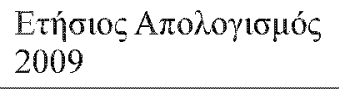 & $\begin{array}{l}\text { http://www.ote.gr/investor/Uploads/ } \\
\text { annualgrfinal.pdf }\end{array}$ \\
\hline $\begin{array}{l}\text { Annual Report } \\
2010\end{array}$ & 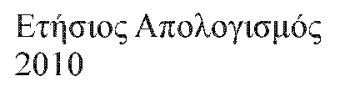 & $\begin{array}{l}\text { http://www.ote.gr/investor/Uploads/ } \\
\text { annualreportgr.pdf }\end{array}$ \\
\hline
\end{tabular}




\begin{tabular}{|c|c|c|}
\hline Document & Document (in Greek) & Availability \\
\hline Form 20-F 1999 & & $\begin{array}{l}\text { http://www.ote.gr/portal/page/portal/ } \\
\text { InvestorRelation/Publications/ } \\
\text { SECFilings }\end{array}$ \\
\hline Form 20-F 2000 & & $\begin{array}{l}\text { http://www.ote.gr/portal/page/portal/ } \\
\text { InvestorRelation/Publications/ } \\
\text { SECFilings }\end{array}$ \\
\hline Form 20-F 2001 & & $\begin{array}{l}\text { http://www.ote.gr/portal/page/portal/ } \\
\text { InvestorRelation/Publications/ } \\
\text { SECFilings }\end{array}$ \\
\hline Form 20-F 2002 & & $\begin{array}{l}\text { http://www.ote.gr/portal/page/portal/ } \\
\text { InvestorRelation/Publications/ } \\
\text { SECFilings }\end{array}$ \\
\hline Form 20-F 2003 & & $\begin{array}{l}\text { http://www.ote.gr/portal/page/portal/ } \\
\text { InvestorRelation/Publications/ } \\
\text { SECFilings }\end{array}$ \\
\hline Form 20-F 2004 & & $\begin{array}{l}\text { http://www.ote.gr/portal/page/portal/ } \\
\text { InvestorRelation/Publications/ } \\
\text { SECFilings }\end{array}$ \\
\hline Form 20-F 2005 & & $\begin{array}{l}\text { http://www.ote.gr/portal/page/portal/ } \\
\text { InvestorRelation/Publications/ } \\
\text { SECFilings }\end{array}$ \\
\hline Form 20-F 2006 & & $\begin{array}{l}\text { http://www.ote.gr/portal/page/portal/ } \\
\text { InvestorRelation/Publications/ } \\
\text { SECFilings }\end{array}$ \\
\hline Form 20-F 2007 & & $\begin{array}{l}\text { http://www.ote.gr/portal/page/portal/ } \\
\text { InvestorRelation/Publications/ } \\
\text { SECFilings }\end{array}$ \\
\hline Form 20-F 2008 & & $\begin{array}{l}\text { http://www.ote.gr/portal/page/portal/ } \\
\text { InvestorRelation/Publications/ } \\
\text { SECFilings }\end{array}$ \\
\hline Form 20-F 2009 & & $\begin{array}{l}\text { http://www.ote.gr/portal/page/portal/ } \\
\text { InvestorRelation/Publications/ } \\
\text { SECFilings }\end{array}$ \\
\hline Form 20-F 2010 & & $\begin{array}{l}\text { http://www.ote.gr/portal/page/portal/ } \\
\text { InvestorRelation/Publications/ } \\
\text { SECFilings }\end{array}$ \\
\hline \multicolumn{3}{|c|}{ Public Power Corporation (PPC) } \\
\hline $\begin{array}{l}\text { Annual Report } \\
2002\end{array}$ & 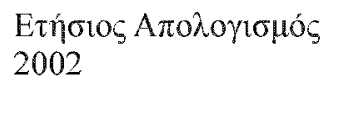 & $\begin{array}{l}\text { http://www.dei.gr/Documents/ } \\
\text { DEI\%20GR-ANNUAL\%20REPORT. } \\
\text { pdf }\end{array}$ \\
\hline
\end{tabular}




\begin{tabular}{|c|c|c|}
\hline Document & Document (in Greek) & Availability \\
\hline $\begin{array}{l}\text { Annual Report } \\
2003\end{array}$ & 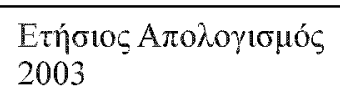 & $\begin{array}{l}\text { http://www.dei.gr/Documents/ } \\
\text { GreAnnual\%202003.pdf }\end{array}$ \\
\hline $\begin{array}{l}\text { Annual Report } \\
2004\end{array}$ & 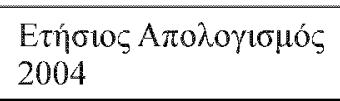 & $\begin{array}{l}\text { http:/www.dei.gr/Documents/ } \\
\text { annual04ell-f.pdf }\end{array}$ \\
\hline $\begin{array}{l}\text { Annual Report } \\
2005\end{array}$ & 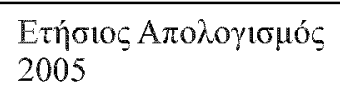 & $\begin{array}{l}\text { http://www.dei.gr/Documents/ } \\
\text { ETHSIODELTIO-GR-05.pdf }\end{array}$ \\
\hline $\begin{array}{l}\text { Annual Report } \\
2006\end{array}$ & 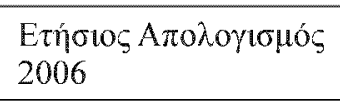 & $\begin{array}{l}\text { http://www.dei.gr/documents/etis.06. } \\
\text { ell.pdf }\end{array}$ \\
\hline $\begin{array}{l}\text { Annual Report } \\
2007\end{array}$ & 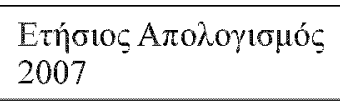 & $\begin{array}{l}\text { http://www.dei.gr/Documents/PPC } \\
\text { DELTIO-GR-07-D9.pdf }\end{array}$ \\
\hline $\begin{array}{l}\text { Annual Report } \\
2008\end{array}$ & 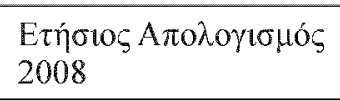 & $\begin{array}{l}\text { http://www.dei.gr/Documents/ } \\
\text { PPCannual.08.gr.pdf }\end{array}$ \\
\hline $\begin{array}{l}\text { Annual Report } \\
2009\end{array}$ & 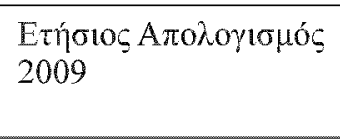 & $\begin{array}{l}\text { http://www.dei.gr/Documents/ } \\
\text { DEH } \% 20 \text { Deltio } \% 202009 \% 20 \mathrm{GR} \% 20 \\
\text { gray.pdf }\end{array}$ \\
\hline $\begin{array}{l}\text { Annual Report } \\
2010\end{array}$ & 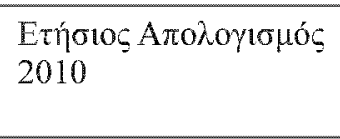 & $\begin{array}{l}\text { http://www.dei.gr/Documents2/ } \\
\text { INVESTORS/ANNUAL \%20 } \\
\text { REPORTS/annual\%20report_GR.pdf }\end{array}$ \\
\hline $\begin{array}{l}\text { Prospectus Jan. } \\
2003\end{array}$ & 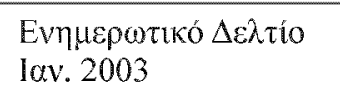 & $\begin{array}{l}\text { http:/www.dei.gr/images/ } \\
\text { enimDeltio29Jan03.pdf }\end{array}$ \\
\hline $\begin{array}{l}\text { Prospectus Oct. } \\
2003\end{array}$ & 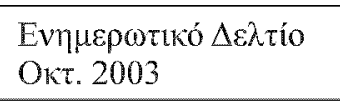 & http://www.dei.gr/images/DEH.pdf \\
\hline $\begin{array}{l}\text { Offering Circular } \\
\text { Dec. } 2002\end{array}$ & & $\begin{array}{l}\text { http://www.dei.gr/images/ } \\
\text { circular_29Jan03.pdf }\end{array}$ \\
\hline $\begin{array}{l}\text { Offering Circular } \\
\text { Oct. } 2003\end{array}$ & & $\begin{array}{l}\text { http://www.dei.gr/images/of_circular_ } \\
\text { oct2003.pdf }\end{array}$ \\
\hline $\begin{array}{l}\text { General Inspector } \\
\text { of Public } \\
\text { Administration } \\
\text { Report on PPC } \\
\text { Inspection } \\
\text { regarding the } \\
\text { Legality of } \\
\text { PPC Financial } \\
\text { Support/ } \\
\text { Subsidies } \\
\text { towards the PPC } \\
\text { Labor Union, }\end{array}$ & 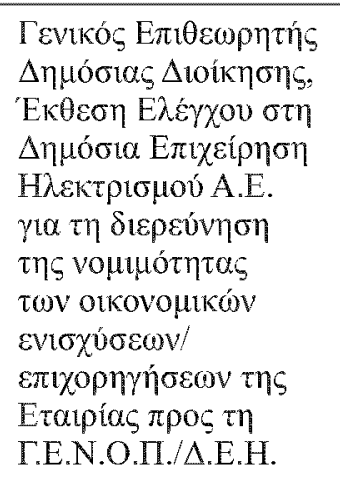 & $\begin{array}{l}\text { http://www.ypeka.gr/LinkClick.aspx?f } \\
\text { ileticket=BUwzyzpxn6A\%3D\&tabid } \\
=367 \& \text { language-el-GR }\end{array}$ \\
\hline
\end{tabular}




\begin{tabular}{|c|c|c|}
\hline Document & Document (in Greek) & Availability \\
\hline \multicolumn{3}{|c|}{ Greek Organization of Football Prognostics (OPAP) } \\
\hline $\begin{array}{l}\text { Annual Report } \\
2001\end{array}$ & 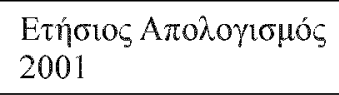 & $\begin{array}{l}\text { http:/www.opap.gr/documents/ } \\
\text { 11503/180176/2001_ETHSIO.pdf }\end{array}$ \\
\hline $\begin{array}{l}\text { Annual Report } \\
2002\end{array}$ & 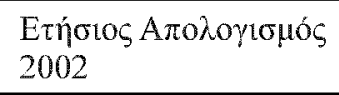 & $\begin{array}{l}\text { http://www.opap.gr/documents/ } \\
\text { 11503/180176/2002_ETHSIO.pdf }\end{array}$ \\
\hline $\begin{array}{l}\text { Annual Report } \\
2003\end{array}$ & 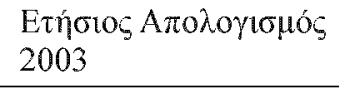 & $\begin{array}{l}\text { http://www.opap.gr/documents/ } \\
\text { 11503/180176/2003_ETHSIO.pdf }\end{array}$ \\
\hline $\begin{array}{l}\text { Annual Report } \\
2004\end{array}$ & 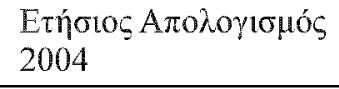 & $\begin{array}{l}\text { http://www.opap.gr/documents/ } \\
\text { 11503/180176/2004_ETHSIO.pdf }\end{array}$ \\
\hline $\begin{array}{l}\text { Annual Report } \\
2005\end{array}$ & 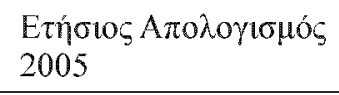 & $\begin{array}{l}\text { http:/www.opap.gr/documents/ } \\
\text { 11503/180176/2005_ETHSIO.pdf }\end{array}$ \\
\hline $\begin{array}{l}\text { Annual Report } \\
2006\end{array}$ & 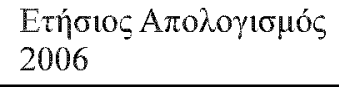 & $\begin{array}{l}\text { http://www.opap.gr/documents/ } \\
\text { 11503/180176/2006_ETHSIO.pdf }\end{array}$ \\
\hline $\begin{array}{l}\text { Annual Report } \\
2007\end{array}$ & 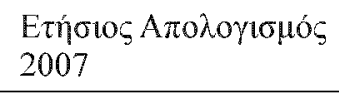 & $\begin{array}{l}\text { http:/www.opap.gr/documents/ } \\
\text { 11503/180176/2007_ETHSIO.pdf }\end{array}$ \\
\hline $\begin{array}{l}\text { Annual Report } \\
2008\end{array}$ & 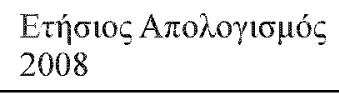 & $\begin{array}{l}\text { http:/www.opap.gr/documents/ } \\
\text { 11503/180176/2008_ETHSIO.pdf }\end{array}$ \\
\hline $\begin{array}{l}\text { Annual Report } \\
2009\end{array}$ & 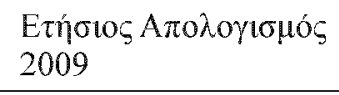 & $\begin{array}{l}\text { http:/www.opap.gr/documents/ } \\
\text { 11503/180176/2009_ETHSIO.pdf }\end{array}$ \\
\hline $\begin{array}{l}\text { Annual Report } \\
2010\end{array}$ & 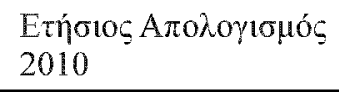 & $\begin{array}{l}\text { http://www.opap.gr/documents/ } \\
11503 / 182631 / \mathrm{fs}+2010+\mathrm{GR}+\text {.pdf }\end{array}$ \\
\hline Prospectus 2001 & 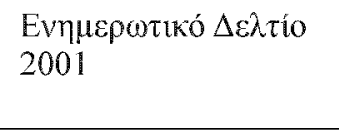 & $\begin{array}{l}\text { http:/www.opap.gr/documents/ } \\
\text { 11503/16736/ENHMER_DELTIO } \\
\text { MART_2001.pdf }\end{array}$ \\
\hline Prospectus 2002 & 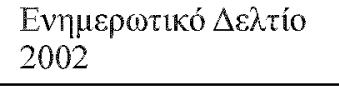 & $\begin{array}{l}\text { http://www.opap.gr/el/web/corporate. } \\
\text { opap.gr/41 }\end{array}$ \\
\hline Prospectus 2003 & 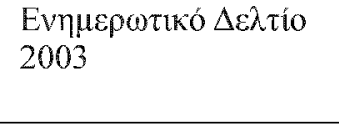 & 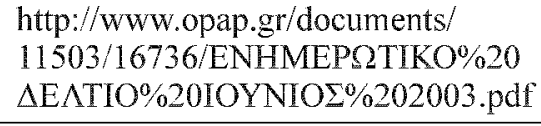 \\
\hline Prospectus 2005 & 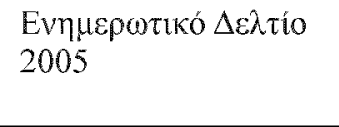 & 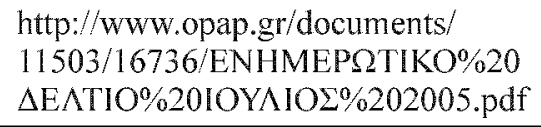 \\
\hline
\end{tabular}

